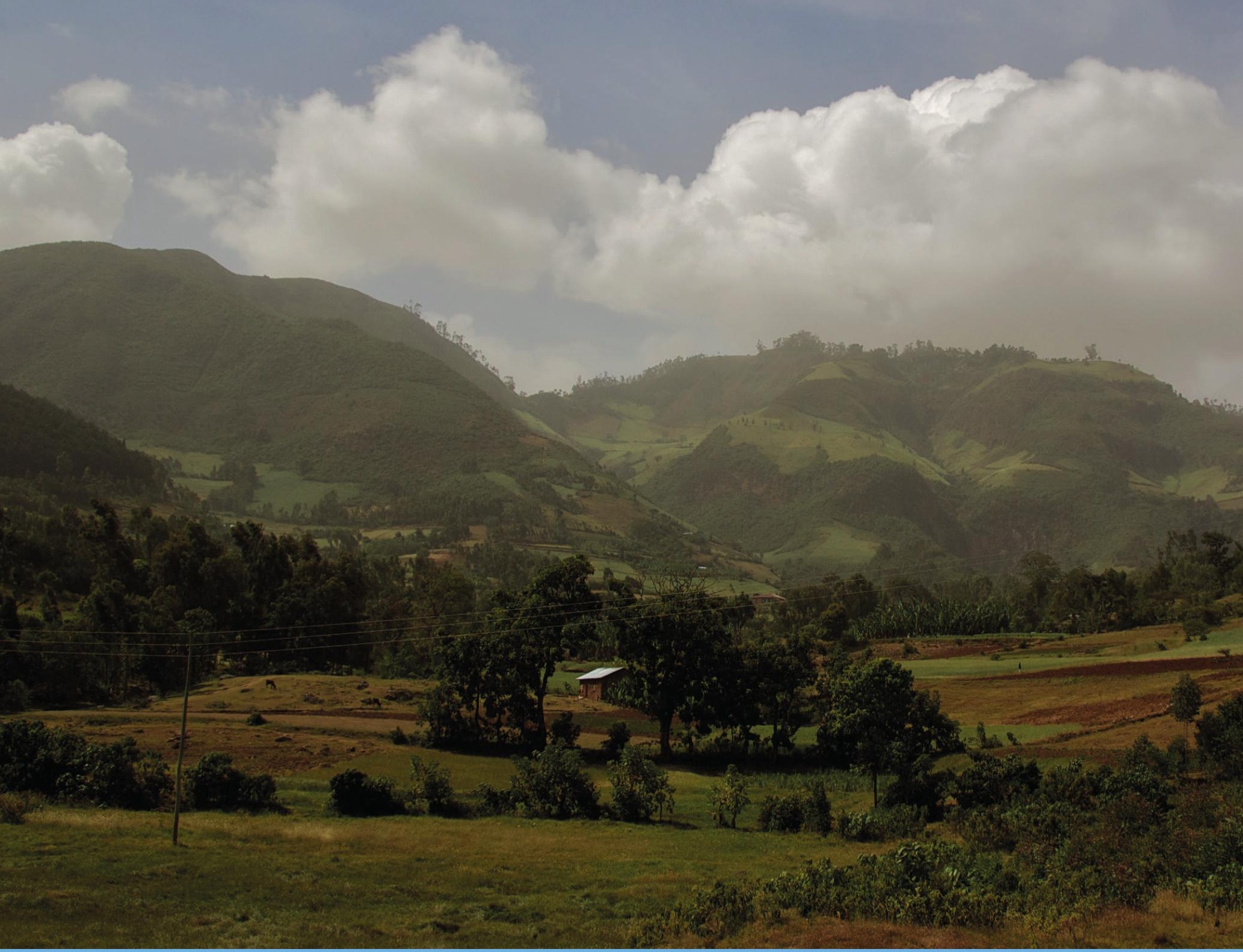

\title{
Modelling Crop Yields and Water Balances for Ethiopia with LPJmL
}

M.I. Hermelink, J.G. Conijn, R. Dankers 



\section{Modelling Crop Yields and Water Balances for Ethiopia with LPJmL}

M.I. Hermelink, J.G. Conijn, R. Dankers

This study was carried out by the Wageningen Research Foundation (WR) business unit Agrosystems Research, and was commissioned and financed by the Wageningen University \& Research "Food Security and Valuing Water" programme, that is supported by the Dutch Ministry of Agriculture, Nature and Food Security (KB-35-005-001), and by the "Protein Transition" programme of Wageningen University \& Research (KB-39).

WR is part of Wageningen University \& Research, the collaboration of Wageningen University and Wageningen Research Foundation.

Wageningen, December 2021

Report WPR-1123 
Hermelink, M.I., J.G. Conijn, R. Dankers, 2021. Modelling Crop Yields and Water Balances for Ethiopia with LPJmL. Wageningen Research, Report WPR-1123. 44 pp.; 12 fig.; 14 tab.; 20 ref.

This report can be downloaded for free at https://doi.org/10.18174/559929

Ethiopia faces climate changes that could impact its food and water security. This report describes the modelling of crop production and water balances for two separate studies on Ethiopia using the Lund Potsdam Jena managed Land (LPJmL) model. For the project Soy10 we modelled the effect of a $10 \%$ shift in protein source from cereals to soybean on land use and water demand, and explored how resilient these crop's yields would be to climate change. For the project Multiple Scales and Extreme Events (MSX) we modelled Ethiopia's crop yields at the rainfed potential level and the corresponding water demand compared to current levels. Results for Soy10 indicate that the assumed protein shift could free up around $2 \%$ of Ethiopia's physical crop area without negatively impacting water availability, and that soybean yields would be more climate resilient than cereals under the selected climate scenario. Results for MSX suggest that Ethiopia has the potential to greatly improve its current yields through production intensification. Intensification would lead to a higher total agricultural water use, but also to greater water use efficiency. Note, however, that results should be interpreted with care, as there are still some points to improve in the modelling process which could affect the results.

Keywords: Ethiopia, LPJmL, food security, land use modelling, protein transition, soybean, rainfed yield potential

(C) 2021 Wageningen, Stichting Wageningen Research, Wageningen Plant Research, Business Unit Agrosystems, P.O. Box 16, 6700 AA Wageningen, The Netherlands; T +31 (0)317 480700 ; www.wur.eu/plant-research

Chamber of Commerce no. 09098104 at Arnhem

VAT NL no. 8065.11.618.B01

Stichting Wageningen Research. All rights reserved. No part of this publication may be reproduced, stored in an automated database, or transmitted, in any form or by any means, whether electronically, mechanically, through photocopying, recording or otherwise, without the prior written consent of the Stichting Wageningen Research.

Stichting Wageningen Research is not liable for any adverse consequences resulting from the use of data from this publication.

Report WPR-1123

Photo cover: Flickr/A. Davey 


\section{Contents}

$\begin{array}{ll}\text { Summary } & 5\end{array}$

1

$\begin{array}{ll}\text { Introduction } & 7\end{array}$

1.1 Project Soy10

1.2 Project Multiple Scales and Extreme Events

$\begin{array}{ll}\text { The LPJmL Model } & 9\end{array}$

3

$\begin{array}{lr}\text { Data Inputs } & 10\end{array}$

$\begin{array}{lll}3.1 & \text { General Inputs } & 10\end{array}$

3.1.1 Region Grid $\quad 10$

$\begin{array}{ll}3.1 .2 \text { Soil type } & 10\end{array}$

3.1.3 Atmospheric $\mathrm{CO}_{2}$ Concentration 11

3.2 Module: Land Use $\quad 11$

3.2.1 Country code $\quad 11$

3.2.2 Land Use 11

3.2.3 Sowing Dates $\quad 12$

3.2.4 Neighbouring Irrigation Sources $\quad 12$

3.3 Module: River Routing 13

3.3.1 Drainage direction 13

$\begin{array}{ll}3.3 .2 \text { Lake fraction } & 13\end{array}$

3.4 Module: Reservoirs 13

3.4.1 Elevation 13

3.4.2 Dam information 13

3.5 Climate Data $\quad 13$

3.5 .1 ISIMIP3b 13

$\begin{array}{ll}3.5 .2 \text { W5E5 } & 14\end{array}$

$\begin{array}{ll}3.5 .3 \mathrm{CRU} & 14\end{array}$

4

$\begin{array}{ll}\text { Simulations } & 16\end{array}$

4.1 Spin-up Run $1 \quad 16$

4.2 Spin-up Run $2 \quad 16$

4.3 Historic Run 16

4.4 Calibration $\quad 16$

4.4.1 Base Temperature 16

4.4.2 Maximum Leaf Area Index 17

4.5 Scenario A: Current Climate \& Land Use 17

4.6 Scenario B: Current Climate + Protein Shift 17

4.7 Scenario C: Future Climate + Protein Shift 18

4.8 Scenario D: Current Climate at Rainfed Potential $\quad 18$

$\begin{array}{llr}5 & \text { Output Processing } & 20\end{array}$

$\begin{array}{lll}5.1 & \text { General } & 20\end{array}$

$\begin{array}{lll}5.2 \text { Yield } & 20\end{array}$

$\begin{array}{lll}5.3 & \text { Growing Days } & 20\end{array}$

$\begin{array}{lll}5.4 & \text { Total Production } & 20\end{array}$

$\begin{array}{lll}5.5 & \text { Precipitation Deficit/Surplus } & 20\end{array}$

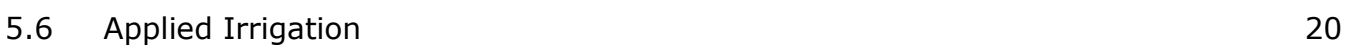


6.1 Results for Soy10 $\quad 21$

6.1.1 Land Use $\quad 21$

6.1.2 Yields and Production $\quad 22$

6.1.3 Precipitation Deficit/Surplus $\quad 24$

6.1.4 Irrigation Demand $\quad 27$

$\begin{array}{lll}6.2 & \text { Results for Multiple Scales } & 27\end{array}$

6.2.1 Yields and Production $\quad 27$

6.2.2 Precipitation Deficit 29

$7 \quad$ Conclusions and Further Research $\quad 30$

$\begin{array}{lll}7.1 & \text { Conclusions for Soy10 } & 30\end{array}$

$\begin{array}{lll}7.2 & \text { Conclusions for Multiple Scales } & 30\end{array}$

$\begin{array}{lll}7.3 & \text { Future Research } & 30\end{array}$

7.3.1 General Points to Address 30

7.3.2 Further Research for Soy10 31

7.3.3 Further Research for Multiple Scales 31

References $\quad 32$

$\begin{array}{lll}\text { Annex } 1 & \text { Supplementary Material } & 34\end{array}$ 


\section{Summary}

Ethiopia, as the rest of the world, is facing looming climate changes, with potentially a great impact on its food and water security. It is of great importance to better understand possible developments in Ethiopia with regards to its food and water availability and use, including the role of Ethiopia as water supplier to its neighbouring countries. In this technical report, we describe the steps and results in modelling crop production and water balances for two separate studies on Ethiopia using the Lund Potsdam Jena managed Land (LPJmL) land use model. For the project Soy10 we modelled the effect of a $10 \%$ shift in protein source from cereals to soybean on land use and water demand, and explored how resilient these crop's yields would be to climate change. For the project Multiple Scales and Extreme Events (MSX) we modelled Ethiopia's crop yields at the rainfed potential level and the corresponding water demand, and compared this to the current yield and water demand levels. A total of four scenarios were modelled:

A. A current scenario: set in the current time, with current climate, production intensity level, and land use (scenario used for Soy10 and MSX).

B. A current scenario with a $10 \%$ protein source shift: set in the current time, with current climate and production intensity level, but with an assumed land use in which part of the cereal area is replaced by soybean area (scenario used for Soy 10 ).

C. A future scenario with a $10 \%$ protein source shift: with current production intensity level, an assumed land use adjustment from cereals towards soybean, and a selected future climate scenario for the period around 2050 (scenario used for Soy10).

D. A potential scenario, set in the current time, with climate and land use modelled as they are now, but with production intensity at the rainfed potential level (scenario used for MSX).

The results of the modelled scenarios led to the following main conclusions for each project.

\section{Conclusions for Soy10}

- A diet shift replacing $10 \%$ of cereal food protein by soybean protein could free up around 238000 ha of physical area of cropland in Ethiopia, which is around $2 \%$ of the country's total cropland area. The higher protein content of soybean compared to cereals allows the production of the same amount of proteins from less land.

- Cereal yields appear to be slightly negatively impacted by the climate scenario selected for this study, while soybean yields are not impacted. It can be concluded that the selected future climate would not significantly alter the results of the shift from cereals towards soybean production as compared to the current climate.

- The dietary shift would also not lead to major changes in water availability for cereals and soybean, and the precipitation deficit of the modified land use situation due to the shift would improve with the selected climate scenario modified. However, it is still necessary to further analyse model outcomes on water balances to better understand these results.

\section{Conclusions for Multiple Scales}

- Ethiopia has the potential to greatly increase its actual yields and thereby its food production by intensifying its crop production. Yields in the main crop cycle could be increased by a factor three up to a factor nine depending on the crop. Such a productivity increase improves Ethiopia's food production without the need for agricultural land expansion.

- A productivity increase would lead to an increased transpiration and decreased evaporation, with a net increase in evapotranspiration (ET). We can thus conclude that production intensification would use a greater portion of Ethiopia's water resources on cropland than the current production intensity.

- However, as yields would increase more steeply than the ET, the higher production intensity would likely lead to a greater water use efficiency. These results still need to be further verified.

Note that the conclusions above should be interpreted with care, as there are still some points to improve in the modelling process which could affect the results. These issues will be addressed in a follow up study. 
Ethiopia, as the rest of the world, is facing looming climate changes, with potentially a great impact on its food and water security. Besides this, Ethiopia, as the rest of Africa, is also facing a large increase of its population in coming decades, up to twice or more its current level. As Ethiopia is largely a water supplier to its neighbouring countries, water availability and use within Ethiopia can impact water and food security in these countries and beyond. It is therefore of great importance to gain a better understanding on the possible developments in Ethiopia with regards to its food and water availability and use, and of the nexus existing between these two essential resources. In this technical report, we describe the steps and results in modelling crop production and water balances for two separate studies on Ethiopia using the Lund Potsdam Jena managed Land (LPJmL) land use model. In both projects, LPJmL was used to perform an explorative study of alternative crop production and climate change scenarios for Ethiopia and their corresponding impacts on water availability/use.

\subsection{Project Soy10}

The project Soy10 is financed by the Protein Transition Investment Theme of Wageningen University, which is aimed at exploring the options and effects of a protein source transition in human diets. In this context, the project explores some environmental effects that a $10 \%$ change in protein source would have in Ethiopia. We refer to this diet change as a shift, rather than a transition, as the change in diet is only partial (10\%), and does not encompass a complete transition of one source to another. The project seeks to answer the following questions:

1. How would a shift of $10 \%$ of the current food protein supply from cereal to soybean affect land use in Ethiopia?

2. How climate resilient would the above shift in protein source be if Ethiopia's climate would develop on the dryer side of the projected climate spectrum? How is the productivity (i.e. yields) of cereals and soybean expected to change under climate change?

3. How would water balances (precipitation deficit or surplus) be affected by the $10 \%$ shift in protein source? And how would they be affected by climate change?

4. How would irrigation demand be affected by the shift, and how would this be affected by climate change?

To answer these questions, we have modelled three scenarios with LPJmL:

E. A current scenario, set in the current time, with climate, production intensity level, and land use modelled as they are now (Soy10 and Multiple Scales).

F. A current scenario with a $\mathbf{1 0 \%}$ protein source shift, set in the current time, with climate and production intensity level as they are now, but with an assumed land use in which part of the cereal area is replaced by soybean area.

G. A future scenario with a $\mathbf{1 0 \%}$ protein source shift, with production intensity level as it is now, an assumed land use adjustment from cereals towards soybean, and a selected future climate scenario for the period around 2050. 


\subsection{Project Multiple Scales and Extreme Events}

The project Multiple Scales and Extreme Events aims to model food production and its effects at multiple scales with different models, in order to gain more insights than is now possible with individual models. In this context, LPJmL is used to simulate potential food production in Ethiopia and its effects on water, and to compare these results with the model BIOSPACS, which projects food demand. The study aims at answering the following questions:

1. What are the potential crop yields under rainfed conditions (i.e. water limited yields) that Ethiopia could currently achieve, and what would be its corresponding food production? How do the potential yields and production compare to the current actual yield and production levels?

2. How would Ethiopia's water balance be affected by crop production at the rainfed potential level compared to current production level?

To answer these questions, we have modelled additionally a fourth scenario in LPJmL (which is compared with scenario A):

H. A potential scenario, set in the current time, with climate and land use modelled as they are now, but with production intensity at the rainfed potential level.

In the next chapters we describe the Lund Potsdam Jena managed Land (LPJmL) land use model in general terms (Section 2), we describe the input data for the model and its preparation (Section 3), outline the calibration process and runs that were performed for the scenarios (Section 4), describe the processing of the outputs (Section 5), report on simulation results (Section 6), and finally make recommendations for further research (Section 7). 


\section{The LPJmL Model}

The Lund Potsdam Jena managed Land model is a dynamic vegetation model developed by the Potsdam Institute for Climate Research (PIK), usually applied at the global or regional scale. In this case, we have used it for an area covered by Ethiopia and its outflowing basins, including the Nile. Inputs for the model consist of gridded data on climate, terrain (elevation, basin network, soil type), and land use. LPJmL uses these data to simulate growth and productivity of natural and agricultural vegetation at grid cell level through water, carbon, and energy fluxes. The resolution used to model at a regional level like Ethiopia is 5 arcmin (10x10 km at the equator). The agricultural vegetation is simulated as crop functional types (CFTs), which are clusters of crops that have been grouped based on their growth characteristics. LPJmL can be used to simulate a wide range of biophysical processes, but for this study we have used it to simulate crop yields at the potential, water limited, and actual level, and their corresponding water balances. For a detailed explanation of LPJmL, Schaphoff et al. (2018) can be consulted. This study made use of LPJmL 4.0.002, which was available as open access on PIK's LPJmL github repository. 


\section{Data Inputs}

This chapter outlines the input data that were used and the transformations performed to use it as input for the LPJmL simulations.

\subsection{General Inputs}

\subsubsection{Region Grid}

LPJmL is a biophysical model and the borders of a simulated region cannot be defined by geopolitical boundaries, but must be defined by basin boundaries. LPJmL cannot simulate sections of basins, only complete basins. In order to simulate the whole area of Ethiopia and the consequences of the water balance in Ethiopia for its water-receiving neighbours, it is necessary to include all the basins present in Ethiopia, including the areas crossing into neighbouring countries. The region to model in LPJmL was delineated using QGIS 3.4.3, a shapefile of Ethiopia, and a worldwide basin shapefile (Lehner et al., 2008). The simulation region was defined by merging all the shapefiles of the basins that had at least some overlap with the shapefile of Ethiopia. The merged shapefile was gridded at a resolution of 5 min and turned into a binary (.bin) file, which is the format required by LPJmL for most input data. The grid was a model input and was also used in the process of transforming further input data into binary (.bin) files.

(A)

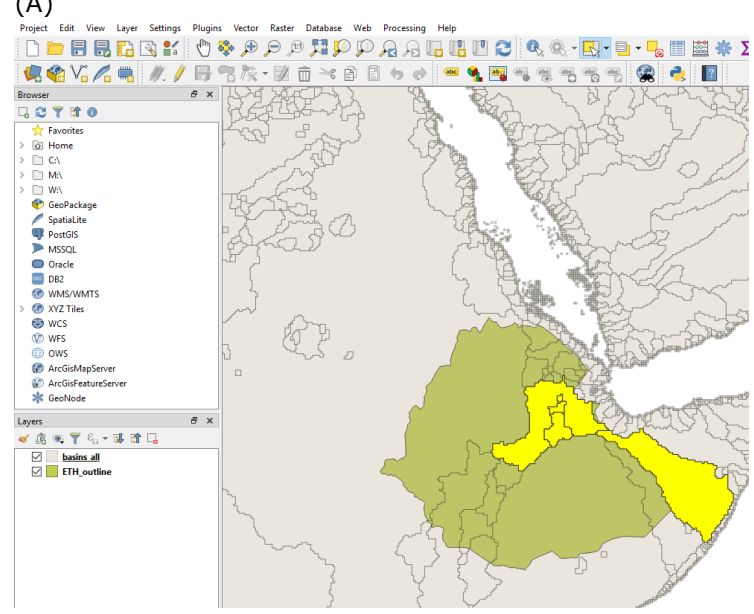

(B)

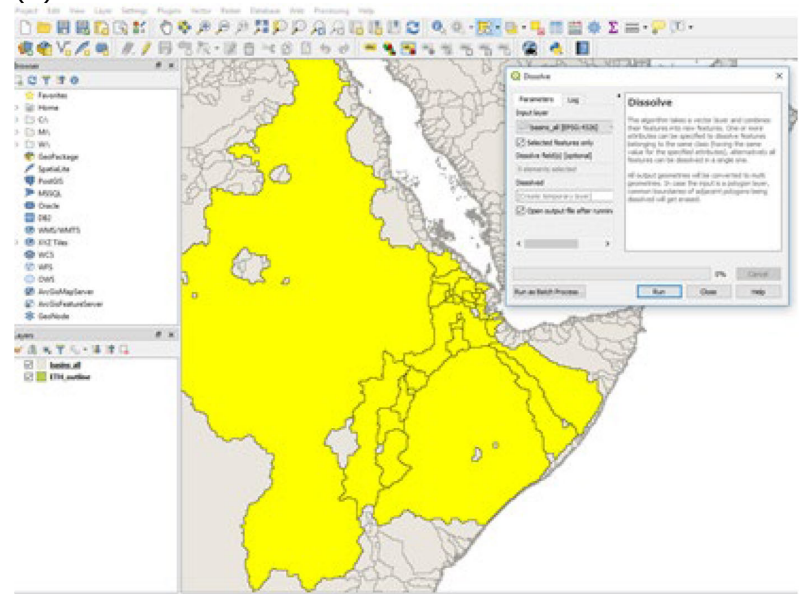

Figure 1 (A) Selection of basin shapefiles overlapping with Ethiopia shapefile in QGIS.

(B) Complete seletion of basin shapefiles, which runs through Egypt into the mediterranean sea.

\subsubsection{Soil type}

LPJmL requires an input file stating the USDA soil texture of each grid cell. Data on soil type were retrieved from the Harmonized World Soil Database (HWSD, (Fischer et al., 2008). The database provided a GIS-file mapping the area covered by different soil units, and an Access data file listing the soil types, their USDA textures and shares (\%) present in each soil unit. The soil type with the highest share was assigned to each soil unit and corresponding grid cell. The grid file with the texture codes of the dominant soil types was then transformed into a binary form. 


\subsubsection{Atmospheric $\mathrm{CO}_{2}$ Concentration}

LPJmL requires a text file listing the $\mathrm{CO}_{2}$ concentration in the atmosphere for each simulation year. This file was provided Wageningen Environmental Research. However, $\mathrm{CO}_{2}$ data were available up to 2014, while historical simulations would be run up to 2016. In order to complete the data entries for the last two years, the following steps were undertaken:

1. The change in $\mathrm{CO}_{2}$ concentration from the previous to the next year was calculated for all years.

2. The data points for $\mathrm{CO}_{2}$ concentration change were plotted for all data points between 1945 and 2014, and a linear regression was performed (see Figure 9 in the Appendix).

3. Regression coefficients were used to estimate $\mathrm{CO}_{2}$ concentration change in 2015 and 2016 relative to 2014 and 2015 respectively. These estimates were then used to estimate absolute $\mathrm{CO}_{2}$ concentrations in 2015 and 2016, which were then manually added to the input file for LPJmL.

\subsection{Module: Land Use}

The land use module is used to simulate managed land for crop production. The module requires the following datasets:

\subsubsection{Country code}

LPJmL requires an input file assigning a country code to each cell in the grid created in Section 3.1. This file was created by first downloading a file with all country shapefiles from NaturalEarth (2021). Each grid cell was assigned its corresponding country name. Subsequently, each country name was associated to its corresponding country code as listed in the file managepar.h in the LPJmL code.

\subsubsection{Land Use}

To simulate crop production, LPJmL needs to know which Crop Functional Types (CFTs) are produced where. An input file is therefore required specifying, for each cell, the cell area fraction assigned to each CFT with and without irrigation. To create this file, the Spatial Production Allocation Model (MapSPAM) dataset for Sub-Saharan Africa in 2017 (IFPRI, 2020) was considered the most suitable data source, as it is the most recent land use dataset that we are aware of and has a suitable resolution of 5 arcmin (circa $10 \times 10 \mathrm{~km}$ at the equator).

The MapSPAM database contains gridded data of the physical and harvested areas of 42 crops. The physical area refers to the actual area where a crop is grown, without taking into account how often the crop was harvested from that area. The sum of all physical areas of the crops in a grid cell is therefore equal or smaller than the cell size. The harvested area is at least as large as the physical area, but can be larger if the crop is harvested more than once in a single year. The sum of the harvest areas of all crops in a grid cell can therefore be larger than the total cell size. As the open source version of LPJmL can only simulate a single growing season for each CFT, it was necessary to use the physical areas rather than the harvested areas of the crops. This has the disadvantage that some of the crop production is not simulated (second growing seasons).

Two separate land use maps were generated using the MapSPAM database:

1. The current land use (circa 2017): The physical areas of all crops were assumed as reported by MapSPAM. This land use map was used to simulate the current scenario (scenario A) used in both Soy 10 and Multiple Scales, and for the potential scenario (scenario D) of Multiple Scales.

2. Land use with a $10 \%$ shift in protein source from cereals to soy: In cells where both soybean and cereals were produced, the harvested area of the cereals was decreased and the harvested area of soybean was increased such that at the national level the cereal food supply was reduced with $10 \%$ and that the soy food supply was increased such that the total food protein supply for the country as a whole remained constant. The new cereals and soybean harvested areas was then transformed to physical areas by dividing by the crop's original cropping intensity (harvested area/physical area, obtained from MapSPAM). The shifted physical areas were used to create this 
land use map. This modified land use map was used for both scenarios with a modified protein source (scenarios B and C) of the project Soy 10 .

The data of crop physical areas of both land use maps were then transformed as follows:

a. The crops were grouped into CFTs according to Table 9 in the Appendix. The grouping listed in the LPJmL Wiki - Crop Functional Types was used as a guideline. To classify the MapSPAM crop 'Other Cereals' into a CFT, it was first necessary to determine which cereals were encompassed into this crop category. According to a crop land use report by Ethiopia's statistical agency (CSA, 2019), the only two cereals produced which are not already listed as individual MapSPAM crops are oats and teff, of which teff covered $98 \%$ of the area. The MapSPAM crop "Other Cereals" was therefore assumed to be teff. Furthermore, to determine whether teff belongs in the CFT "Tropical Cereals" or "Temperate Cereals", crop characteristics were compared to CFT parameterization. The CFT "Temperate Cereals" has a vernalization requirement and a base temperature of $0{ }^{\circ} \mathrm{C}$, while the CFT "Tropical Cereals" does not require vernalization and has a base temperature of $10{ }^{\circ} \mathrm{C}$ (Bondeau et al., 2007). According to Paff (2018), teff does not require vernalization, and has a base temperature between 7 and $7.8^{\circ} \mathrm{C}$. It was therefore classified into the CFT "Tropical Cereals".

b. The physical areas of all crops in each CFT were summed. This was done separately for rainfed and irrigated areas, resulting in 32 land use values for each cell (16 rainfed CFT and 16 irrigated CFTs).

c. The land use value of the CFTs were transformed from absolute land (in hectares) to cell area fractions.

d. The CFT fraction data were transformed into binary files.

\subsubsection{Sowing Dates}

LPJmL can perform a simulation with or without input data on sowing dates of the CFTs. If sowing dates are provided, then the sowing dates are fixed at the indicated day of the year for each CFT in each cell. If dates are not provided, then sowing dates are simulated based on a set of rules and thresholds. One of the aims of this study is to examine the effect of climate change on Ethiopia's food and water availability. An important aspect of climate change is the shift in the onset and length of growing seasons, so to understand the effect of these changes on crop production it was decided to run simulations with a dynamic sowing date.

LPJmL distinguishes four different types of seasonalities: (a) no seasonality, (b) precipitation seasonality, (c) temperature seasonality, and (d) precipitation and temperature seasonality. The climate of Ethiopia is categorized as (b) precipitation seasonality, so sowing dates are only dependent on moisture availability. For this type of seasonality, it is assumed that farmers sow at the start of the main rainy season. In order to identify the main wet season, LPJmL uses the ratio of precipitation to potential evapotranspiration (P/ET) to characterize the wetness of each month. The main wet season is defined as the largest sum of P/ET of four consecutive months, and with the sowing date defined as the first day of the main wet season with a precipitation higher than $0.1 \mathrm{~mm}$. For more detailed information on LPJmL's sowing dates and seasonality LPJmL Wiki - Sowing Dates can be consulted.

\subsubsection{Neighbouring Irrigation Sources}

To be able to simulate irrigated cells, it is necessary to provide input on the neighbouring irrigation sources available for each grid cell. This information is provided in the form of an input file containing, for each grid cell, the ID of the neighbouring grid cell with the largest water flow accumulation that is within the same basin. The identified neighbouring cell is then viewed as a potential source of irrigation water in case of limited water availability in the evaluated cell. Flow accumulation were searched for all cells within a $21 \times 21$ grid around the cell being evaluated (10 grid cells in each direction plus the cell being evaluated in the middle, at 5 arcminutes resolution). For more information on this input file LPJmL Wiki - Inputs can be consulted. 


\subsection{Module: River Routing}

LPJmL allows for lateral exchange of water discharge between cells towards a river network. Water excess is transferred to one if its eight neighbouring cells based on the cell's drainage direction, moving towards the cell's corresponding basin. This module allows for LPJmL's river routing. For more information on the river routing function visit the LPJmL Wiki - River routing. The module requires the following input data:

\subsubsection{Drainage direction}

Data on drainage direction at 5 arcminutes resolution was accessed from the HydroSHEDS dataset (Lehner et al., 2008). The data was transformed to a binary (.bin) form.

\subsubsection{Lake fraction}

Data on the percentage of each cell covered by open fresh water is indicated in the lake fraction input file. These data were provided by Wageningen Environmental Research in raster form, but were originally obtained as polygons from the Global Lakes and Wetlands Database (GLWD) (Lehner \& Döll, 2004). The raster data were transformed to a binary form. For more information on this input file LPJmL Wiki - Inputs can be consulted.

\subsection{Module: Reservoirs}

Reservoirs are modelled in LPJmL as they have an impact on the discharge flow downstream of the dam and because they can provide water for irrigation. More information on the reservoir module can be found on LPJmL Wiki - Dams and reservoirs. LPJmL requires the following data to use the reservoir module:

\subsubsection{Elevation}

Data on elevation above sea level is necessary because it is assumed that only cells that are at a lower altitude than a reservoir can get water from it. Elevation data were downloaded from the Harmonized World Soil Database (Fischer et al., 2008) and transformed to a binary form.

\subsubsection{Dam information}

General information on the dams (location, year they were build, capacity (volume), area, main purpose (irrigation, hydropower, or other) was obtained through the Global Reservoir and Dam Database (GRanD) (Lehner et al., 2011). The coordinates of the reservoirs were visually examined and manually relocated in QGIS 3.4.3, such that they were overlapping the river network of the Hydrosheds dataset (Lehner et al., 2008). The dataset was then transformed into a binary file.

\subsection{Climate Data}

LPJmL was run with three different climate datasets, each described below.

\subsubsection{ISIMIP3b}

To run scenario $\mathrm{C}$ for the project Soy10, set in Ethiopia's future, LPJmL was run with a future climate scenario. This scenario was selected from the scenarios provided by the Intersectoral Impact Model Intercomparison Project (ISIMIP). ISIMIP is a collaboration of research institutions worldwide, evaluating the impact of climate change scenarios on different economic sectors through modelling. The project takes climate scenario datasets of the Coupled Model Intercomparison Project (CMIP) and performs a bias correction on them. The bias-corrected datasets are made available to the 
participating institutions to use as input to their sector models. This has the advantage that results across models of different institutes are more inter-comparable, as they use the same climate data input and bias-correction (ISIMIP, 2021).

The most recent climate data provided by ISIMIP is the ISIMIP3b dataset, in which scenarios of the CMIP's latest simulation round, CMIP6, were bias corrected. This dataset was selected to run the LPJmL future scenario mainly because (a) it is the most recent climate scenario data available, (b) this dataset has a relatively high resolution, despite the fact that it is a global dataset (30 arcminutes, $\left.0.5^{\circ}\right)$, (c) the data are already bias-corrected, and (d) it allows comparability of LPJmL simulation results with other modelling outputs for the agricultural and water sectors of ISIMIP.

In the ISIMIP3b dataset there were three climate scenarios available, each being a specific combination of a shared socioeconomic pathway (SSP) and a representative concentration pathway (RCP). The three scenarios available are SSP1-RCP2.6, SSP3-RCP7.0 and SSP5-RCP8.5, with respectively an increasingly drastic level of climate change (see full SSP-RCP matrix in Figure 10 in the Appendix). Ideally, all three scenarios would have been used as input for the simulations with LPJmL. However, as the analysis was restricted by time availability, it was decided to use the middle scenario SSP3-RCP7.0. This was considered the most likely scenario, and it was the closest to the 'middle of the road'.

Data from each scenario were available as simulated by five different global circulation models (GCMs): GFDL-ESM4, IPSL-CM6A-LR, MPI-ESM1-2-HR, MRI-ESM2-0, UKESM1-0-LL. Again, ideally all five datasets would have been run with $L P J m L$, but this was not possible in practice, so only one GCM was selected. GCM selection was performed based on their precipitation predictions, as this is the climatic variable where GCMs tend to disagree most on, both in terms of geographic distribution and in absolute values (WorldBank, 2021). As this study intends to determine whether water availability might become a problem for food production, the scenario was selected that was the most limiting in terms of precipitation. Average daily precipitation in a rectangular area encompassing Ethiopia was plotted for every year from 2016 - 2070 for all five GCMs, and their slopes were estimated with a linear trendline (see encompassed area in Figure 11 and scatterplots with trendlines in Figure 12 in the Appendix). The scenario with the lowest placed trendline was selected, as it had the lowest average daily precipitation, which was GFDL-ESM4.

The climate data of the climate scenario SSP3-RCP7.0 and model GFDL-ESM4 was retrieved from the PIK ESGF node, spanning from 2016 to 2050. All units were transformed to the units stated in Table 1 . The downloaded variables were temperature, precipitation, and long and short wave downwelling radiation, all available as daily values as required in the simulations of LPJmL. The average temperature and annual precipitation in Ethiopia projected by the climate scenario are shown in Figure 2 and were used to simulate scenario $\mathrm{C}$, set in the future with a dietary shift, for the project Soy 10.

\subsubsection{W5E5}

The W5E5 climate dataset (Lange, 2019) was used to simulate the scenarios set in the current time of both projects (scenarios $A, B$, and D). This dataset were selected because it is the dataset with which the ISIMIP3b climate scenarios were bias-corrected, and is therefore the historic climate assumed by our climate scenario before its starting point. The W5E5 dataset was retrieved from the PIK ESGF node. All units were transformed to the units stated in Table 1 . The downloaded variables were temperature, precipitation, and long and short wave downwelling radiation, all available as daily values as required in the simulations of LPJmL. The average temperature and annual precipitation in Ethiopia according to the W5E5 dataset are shown in Figure 2.

\subsubsection{CRU}

The Climatic Research Unit (CRU) Time Series 3.10 is a global historic climatic dataset with monthly values (Jones \& Harris, 2013). The CRU dataset is generated based on observations at meteorological stations on land and gridded to a resolution of 30 arcminutes $\left(0.5^{\circ}\right)$ resolution. All data files spanned from 1901 to 2009. 
The CRU dataset was used for spin-up and historical simulations with LPJmL spanning the time before the scenarios of the projects Soy10 and Multiple scales (see Table 2). The climatic variables used from this dataset were temperature, monthly precipitation, wet days per month, and cloudiness. When precipitation data is provided to LPJmL as monthly values, the average number of wet days per month must also be provided, which LPJmL then uses to randomly generate daily precipitation values. Cloudiness is used to calculate radiation values when these values are not supplied directly.

Table 1 Climatic variables and their respective units used for simulations with LPJmL.

\begin{tabular}{lccc} 
Climatic variable & CRU & W5E5 & ISIMTP3b \\
Temperature & ${ }^{\circ} \mathrm{C}$ & ${ }^{\circ} \mathrm{C}$ & $\mathrm{kg} / \mathrm{m}^{2} / \mathrm{day}$ \\
\hline Precipitation & $\mathrm{kg} / \mathrm{m}^{2} / \mathrm{month}$ & $\mathrm{kg} / \mathrm{m}^{2} / \mathrm{day}$ & - \\
\hline Wet days per month & days & - & - \\
\hline Cloudiness & $\%$ & - & $\mathrm{W} / \mathrm{m}^{2}$ \\
\hline Long Wave Downwelling Radiation & - & $\mathrm{W} / \mathrm{m}^{2}$ & $\mathrm{~W} / \mathrm{m}^{2}$ \\
\hline Short Wave Downwelling Radiation & - & $\mathrm{W} / \mathrm{m}^{2}$ & \\
\hline
\end{tabular}
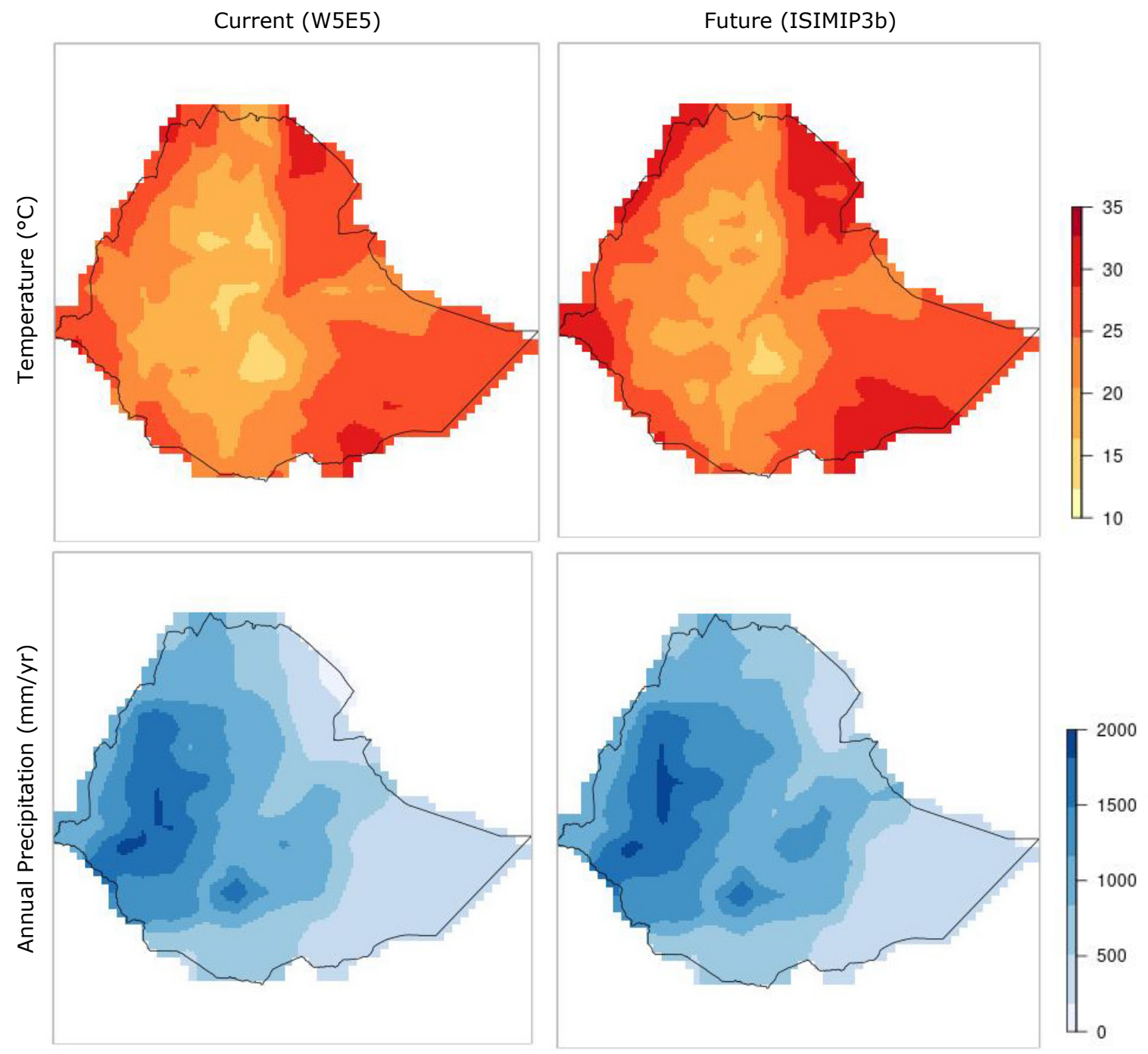

Figure 2 Average temperature and precipitation in the current scenario (W5E5 dataset) and future scenario (ISIMIP3b, SSP370, GFDL-ESM4). Averages were calculated over the period of 19862016 and 2036-2065 for the current and the future situation respectively. 


\section{$4 \quad$ Simulations}

LPJmL was run multiple times with different purposes, as explained in the sections below. An overview of the chronologic sequence and time period covered by each simulation can be found in Table 2 , and the exact settings used for the simulations are stated in Table 11 of the Appendix.

\subsection{Spin-up Run 1}

LPJmL works with a carbon and water pool in each cell. The pools start off at 0 at the beginning of the first simulation and increase in time until they reach approximately a steady state. A first spin-up simulation of around 5000 years was performed with only natural vegetation (no land use data) to reach the equilibrium state of the pools. This simulation was performed with the first 30 years of the CRU dataset (1901 - 1930). LPJmL takes these 30 years of climate data repeatedly during those 5000 years. The carbon and water pools at the end of the spin-up are saved to a restart file for the year 1901, which was used as the starting point for the next simulation. More information on LPJmL's spin-ups can be found at the LPJmL Wiki - How To.

\subsection{Spin-up Run 2}

A second spin-up was performed starting from the restart file of spin-up 1 . This second spin-up had a time span of 390 years and was this time run with the land use as explained in section 3.2.2, with the purpose of having more realistic soil property changes as a result of agricultural activities. This spin-up was also performed using the CRU dataset of 1901 - 1930, and the carbon and water pools of each cell were saved to a restart file as a starting point for the next simulation. More information on LPJmL's spin-ups can be found at the LPJmL Wiki - How To.

\subsection{Historic Run}

Using the soil pools generated by the second spin-up as a starting point, a historic simulation was run from 1901 to 1979 , with the CRU climate data in this period and the land use as in the second spinup. This historic run had the purpose of simulating the changes occurring in the soil and water balances during those first eight decades after 1901 as a result of the actual climate that occurred. The final pool sizes in 1979 were saved to a restart file as the starting point for the next simulations.

\subsection{Calibration}

LPJmL was calibrated through two different parameters, using historical FAOSTAT yields as a reference.

\subsubsection{Base Temperature}

The base temperature (BT) is a parameter provided by LPJmL for each CFT. Only in two CFT's we made adjustments in the values provided by LPJmL. The BT of the CFT Tropical Cereals was changed from the original $10^{\circ} \mathrm{C}$ to $7.8^{\circ} \mathrm{C}$, which is the base temperature of teff (Paff \& Asseng, 2019). The base temperature of maize was variable between $5^{\circ} \mathrm{C}$ and $15^{\circ} \mathrm{C}$, depending on the average temperature in a cell. However, this resulted in yields that were too low when compared to current yields (FAOSTAT, 2021) and also when compared to other crop simulation studies such as the Global 
Yield Gap Atlas (GYGA). We therefore opted to set the BT of maize at $10^{\circ} \mathrm{C}$ following Ogutu et al. (2018) using the WOrld FOod STudies (WOFOST) crop model, which resulted in yields which were more in line with expected values.

\subsubsection{Maximum Leaf Area Index}

The main parameter through which the yield of LPJmL is calibrated is the Maximum Leaf Area Index (LAImax) (Fader et al., 2010). The Leaf Area Index (LAI) is the leaf area per unit ground area, and is a measure of how efficiently plants can capture incoming light. In LPJmL, the LAImax parameter of a CFT is its maximum attainable LAI, and is defined as a value ranging from 1 to 7. As LPJmL does not model any crop management practices other than irrigation (such as fertilization, weeding, or pest and disease control), LAImax is used as a proxy to indicate production intensity level. The parameter must be indicated specifically for each CFT in each country and there is only one value for the whole country. LAImax is directly coupled to two other parameters: the Maximum Harvest Index (HImax) and the AlphaA (a-a). The maximum harvest index indicates the fraction of the aboveground biomass belonging to the harvestable product in the absence of water stress, and is used as a proxy for crop variety. AlphaA is a parameter that scales biomass production from leaf level to stand level, following LAImax. Both the HImax and AlphaA are also CFT and country specific. Together, the LAImax, HImax, and AlphaA parameters are a package emulating the effect of management on crop production. As HImax and AlphaA are directly dependent on LAImax, only the LAImax requires calibration. For more detailed information on LAImax, HImax, AlphaA, or the calibration process, Fader et al. (2010) can be consulted.

LAImax values for each CFT and country combination are provided by LPJmL, but are based on data up to 2009. It was therefore considered necessary to re-calibrate the LAImax values with more recent yield data for Ethiopia, as this was the focus country of the studies, while the values for other countries covered by the simulated region were not changed. The calibration was performed by running LPJmL at all seven integer LAImax levels. The simulated yields of each CFT at each LAImax were averaged for the years 2000 to 2016 at the national level of Ethiopia (Table 13 in the Appendix). The year 2000 was selected as the cut-off year as a compromise between having enough years (=17) to average out climatic variations, and reflecting recent increases in productivity in Ethiopian crop production compared the decades between 1980 and 2000 (Taffesse et al., 2012).

The average yield of each CFT at each LAImax was compared to the average yield of each CFT according to FAOSTAT data for the same period. To compute the average FAOSTAT yields, all crops produced in Ethiopia were grouped into the CFTs as shown in Table 10 in the Appendix. The CFT yields were estimated as the weighted average of the crop yields grouped into the CFT as reported in FAOSTAT. The weights used in the average was the production of the crop relative to the total production of all crops in the CFT. The simulated yields at all LAImax levels were compared to the FAOSTAT average yield, and the LAImax value with the simulated yield closest to the FAOSTAT yield was selected. These LAImax values were used for all further runs performed with LPJmL.

\subsection{Scenario A: Current Climate \& Land Use}

After calibration, a simulation was performed for the period 1979 up to 2016 with the W5E5 climate dataset to simulate scenario A, i.e. the current climate in Ethiopia, used both for the project Soy 10 and Multiple Scales. This run was performed using the land use map as generated with the most recent MapSPAM data (Section 3.2.2).

\subsection{Scenario B: Current Climate + Protein Shift}

In scenario B, a second simulation was performed with the W5E5 dataset from 1979 to 2016, but with the land use map reflecting a $10 \%$ shift in protein source at the national level from cereals to soybean (Section 3.2.2). 


\subsection{Scenario C: Future Climate + Protein Shift}

In scenario C, a future climate situation in Ethiopia was simulated for the period 2016 to 2065, with the ISIMIP3b climate projection and the above mentioned land use map reflecting the protein shift.

\subsection{Scenario D: Current Climate at Rainfed Potential}

A final simulation was performed in scenario D. This run used the W5E5 climate dataset and the land use map based on the MapSPAM dataset. To simulate production at the rainfed potential level, the simulation disregarded the calibrated LAImax values for each CFT and assumed an LAImax value of 7 for all CFTs. 


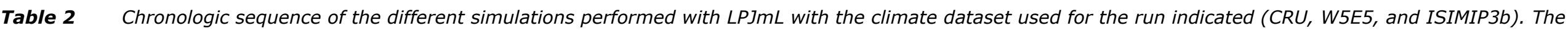

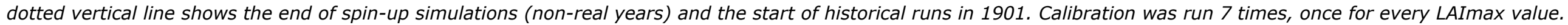
Note that simulations with W5E5 climate data run up to 2016 (not 2020).

\begin{tabular}{|c|c|c|c|c|c|c|c|c|c|c|c|c|c|c|c|c|c|}
\hline Simulation & -5000 & -390 & 1910 & 1920 & 1930 & 1940 & 1950 & 1960 & 1970 & 1980 & 1990 & 2000 & 2010 & 2020 & 2030 & 2040 & 2050 \\
\hline \multicolumn{18}{|l|}{ Spin-up Run 1} \\
\hline Spin-up Run 2 & & CRU & & & & & & & & & & & & & & & \\
\hline Historic Run & & & CRU & & & & & & & & & & & & & & \\
\hline Calibration (x7) & & & & & & & & & & W5E5 & & & & & & & \\
\hline $\begin{array}{l}\text { Scenario A: } \\
\text { Current Climate \& Land Use }\end{array}$ & & & & & & & & & & W5E5 & & & & & & & \\
\hline $\begin{array}{l}\text { Scenario B: } \\
\text { Current Climate + Protein Shift }\end{array}$ & & & & & & & & & & W5E5 & & & & & & & \\
\hline $\begin{array}{l}\text { Scenario C: } \\
\text { Future Climate + Protein Shift }\end{array}$ & & & & & & & & & & & & & & ISIMIP3b & & & \\
\hline $\begin{array}{l}\text { Scenario D: } \\
\text { Current Climate at Rainfed Potential }\end{array}$ & & & & & & & & & & W5E5 & & & & & & & \\
\hline
\end{tabular}




\section{$5 \quad$ Output Processing}

\section{$5.1 \quad$ General}

All outputs were averaged to cover a period of 30 years, taken either from 1986 to 2016 (current climate) or 2036 to 2065 (future climate), respectively.

\subsection{Yield}

LPJmL generates yield output in grams of harvested carbon per square metre per year ( $\mathrm{g} \mathrm{C} / \mathrm{m} 2 / \mathrm{y})$. These results were transformed to tons of fresh weight per hectare according to Equation [1], with $Y_{C}$ and $Y_{F W}$ the yield in the old and new units respectively, $C$ the carbon content ( $\mathrm{g} \mathrm{C} / \mathrm{g}$ dry matter), and $D M C$ the dry matter content ( $\mathrm{g}$ dry matter/g fresh weight). The carbon content was assumed to be a constant value of 0.45 for all CFTs, following Fader et al. (2010). The dry matter content for each CFT can be found in Table 12 in the Appendix and was assumed to be independent of the simulated climate situation.

$$
Y_{F W}=Y_{C} * \frac{1}{C} * \frac{1}{D M C} * 10^{-2}
$$

\subsection{Growing Days}

The number of growing days of each CFT is calculated as the number of days between sowing and harvest. As LPJmL only simulates a single main growing cycle for each CFT, the number of growing days always refers to that single growing cycle.

\subsection{Total Production}

The total production of each CFT was calculated by multiplying the physical area in each grid cell with its respective simulated yields, and summing over all grid cells. Total production therefore does not include the production that could have been achieved in the second growing season. It was decided to not use the harvested area to calculate total production because the yield of the second growing season could differ substantially from the yield in the first season.

\subsection{Precipitation Deficit/Surplus}

The precipitation deficit was calculated specifically for cereals and soybean. The yearly actual evapotranspiration (ET, in $\mathrm{mm} / \mathrm{y}$ ) of the cereal CFTs (temperate cereals, rice, maize, and tropical cereals) and soybean CFT were summed into one value for the combination of these CFT's. The difference between the yearly precipitation and the combined cereal and soy ET was computed and used as a measure for the precipitation deficit (positive values) or surplus (negative values).

\subsection{Applied Irrigation}

LPJmL generates output on the applied irrigation across all crops in each irrigated cell (in mm/yr). These applied irrigation values were multiplied with the total irrigated area in each grid cell across all crops to obtain the total irrigated water volume per cell. These water volumes have been aggregated to calculate a single value for the whole country in each year. 


\section{$6 \quad$ Results}

\subsection{Results for Soy10}

\subsubsection{Land Use}

The current and modified land use of each CFT are reported in Table 3. There are a few practical points to note on the table:

- The areas of the temperate and tropical roots are zero because the tuber crops potato, sweet potato, and yams were mistakenly classified into the CFT 'Other' rather than into the CFTs Temperate Roots and Tropical Roots, following the table of the LPJmL wiki (LPJmL Wiki - Crop Functional Types). In the future these crops need to be reclassified and the simulations (including the calibration) need to be re-run with the adjusted areas.

- There is an increase of 1166 hectares of pulses in the modified land use map. As the shift was applied only to the cereal and soybean CFTs, it is unclear why there was also a shift in the area of pulses. This needs to be investigated further, to determine where the mistake occurred in determining the new areas. The total change in physical area should be increased by 1166 ha.

- The CFTs Groundnuts, Rapeseed, Sugarcane, and Others have a change in area between 1 and 9 hectares. This can be attributed to rounding errors.

We can conclude the following points from the information in the table:

- Irrigated areas are very limited in Ethiopia, to the point that they can be considered negligible. With the exception of sugarcane, irrigated crop area percentages range from 0 to $3.75 \%$, making irrigated agriculture almost irrelevant in the current agricultural production system in most areas of Ethiopia.

- Cereals cover the vast majority of agricultural land in Ethiopia, with wheat, maize, and teff (covered by Temperate Cereals, Maize, and Tropical Cereals respectively) being the dominant crops. Rice does not play a significant role in the Ethiopian cereal production.

- The diet shift sourcing $10 \%$ of the cereal proteins from soybean could free up around 238000 ha of agricultural land, which is around $2 \%$ of the total physical crop area of Ethiopia. The higher protein content of soybean compared to cereals leads to a higher protein yield per hectare, therefore allowing for the production of the same amount of proteins on less land.

Table 3 Total physical area (rainfed and irrigated, in ha) and percentage irrigated area (\%) for each Crop Functional Type (CFT) in the current land use (Scenario A) according to MapSPAM and with a $10 \%$ shift of protein source from cereal to soybean (Scenarios B \& C). The change in area (ha) covered by each CFT is indicated in the last column.

\begin{tabular}{|c|c|c|c|c|c|}
\hline \multirow[b]{2}{*}{ CFT } & \multicolumn{2}{|c|}{$\begin{array}{c}\text { Scenario A: } \\
\text { Current Land Use }\end{array}$} & \multicolumn{2}{|c|}{$\begin{array}{l}\text { Scenarios B \& C: } \\
\text { Modified Land Use }\end{array}$} & \multirow[b]{2}{*}{ Change (ha) } \\
\hline & Area (ha) & Irrigated (\%) & Area (ha) & Irrigated $(\%)$ & \\
\hline Temperate Cereals & $2,207,519$ & 0.53 & $2,141,736$ & 0.54 & $-65,783$ \\
\hline Rice & 31,304 & 0.08 & 28,033 & 0.03 & $-3,271$ \\
\hline Maize & $1,194,663$ & 1.88 & $1,100,517$ & 2.00 & $-94,146$ \\
\hline Tropical Cereals & $4,310,761$ & 0.66 & $3,923,729$ & 0.71 & $-387,032$ \\
\hline Pulses & $1,040,809$ & 0.20 & $1,041,975$ & 0.20 & 1,166 \\
\hline Temperate Roots & 0 & - & 0 & - & 0 \\
\hline Tropical Roots & 0 & - & 0 & - & 0 \\
\hline Sunflower & 0 & - & 0 & - & 0 \\
\hline Soybean & 30,010 & 0.42 & 342,026 & 0.04 & 312,016 \\
\hline Groundnuts & 68,418 & 3.75 & 68,417 & 3.75 & -1 \\
\hline Rapeseed & 22,941 & 0.00 & 22,932 & 0.00 & -9 \\
\hline Sugarcane & 16,113 & 30.00 & 16,112 & 30.00 & -1 \\
\hline Others & $3,125,281$ & 3.24 & $3,125,279$ & 3.24 & -2 \\
\hline Total & $12,047,819$ & 1.44 & $11,810,756$ & 1.46 & $-237,063$ \\
\hline
\end{tabular}




\subsubsection{Yields and Production}

To examine the climate resilience of the dietary shift from cereals to soybean, we simulated the effect of climate change on the yield of these crop types. We compare the yields of scenario $B$, a modified land use with the current climate, and scenario C, a modified land use with the future climate. The average yields of the cereal and soybean CFTs are shown in Figure 3 for both climates in Ethiopia under rainfed $(A)$ and irrigated (B) conditions (yield maps can be found in Table 14 in the Appendix). As a reference, the average yields based on FAOSTAT data between 2000 and 2016 are indicated with red lines. The relative change in yield as a result of climate change is indicated in Table 4, and the average number of growing days with the current and future climate are stated in Table 5. A practical point to note:

- The FAO yields were also used for the model calibration (see Table 13 in the Appendix), so the rainfed yields in the current situation should be close to the FAO averages. This is the case for most crops in the figure except for Temperate cereals. It is unclear why there is such a large difference between these simulated and FAO yields, and due to time limitations it was not possible to further investigate this.

- In the FAO data we could not distinguish between rainfed and irrigated, so the FAO average yields in Figure 3 are the same for both production situations per crop.

Based on the information in the figure and tables below, we can conclude the following points:

- All irrigated cereal yields are equal or lower than their rainfed yields, except for rice. This suggests that water is might not be the most limiting factor in Ethiopia for the production of these crops.

- Under both rainfed and irrigated conditions, cereal yields are projected to decrease with the future climate (with the exception of rice), with relative changes ranging from $-3 \%$ for the Temperate Cereals to $-17 \%$ for the tropical cereals (Table 4 ).

- The decrease in cereal yields with the future climate can in part be explained by the shorter growing season faced by these crops with the future climate (see Table 5). Maize and tropical cereals respectively lose 25 and 16 growing days, amounting to $16 \%$ and $12 \%$ of their total growing days compared to the situation with the current climate.

- Due to the decrease in yield, total production of all cereals from the main growing cycle is predicted to decrease as a result of climate change except for rice (Figure 4). However, as rice covers such a small area in Ethiopia, its total production is a minimal contribution to the total Ethiopian cereal production, and its production increase is considered negligible compared to this total production. Note that the total annual cereal production values are higher due to cultivating on average more than one crop cycle per year.

- On the other hand, the yield of soybean is projected to remain constant in the face of the future climate, and even to increase under irrigated conditions. Its total production is therefore expected to remain stable.

- Overall, soybean seems a more climate resilient crop than cereals under this specific climate scenario. Soybean's yield seems to remain constant while the yields of the relevant cereals are projected to decline. It therefore seems that the savings on land as a result of the dietary shift from cereals to soybean could be maintained and possibly even increased in the future despite climate change as selected for Ethiopia in this study. 
(a) Rainfed

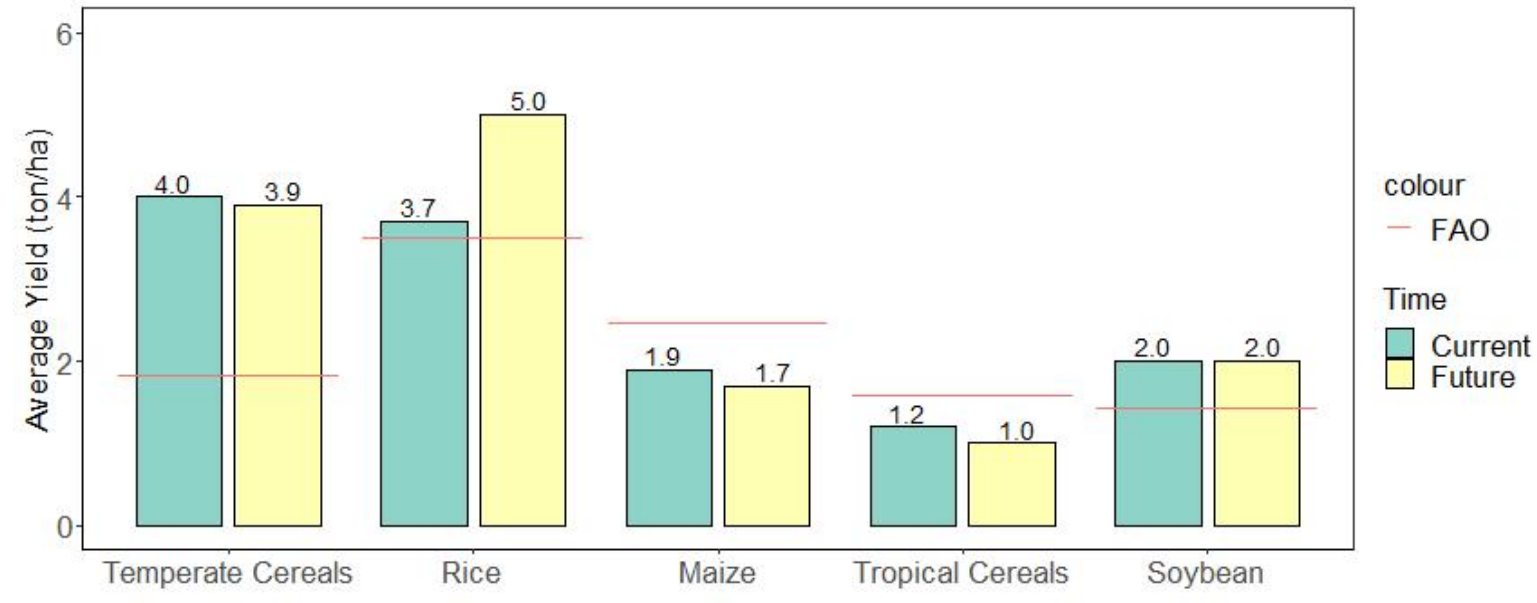

(b) Irrigated

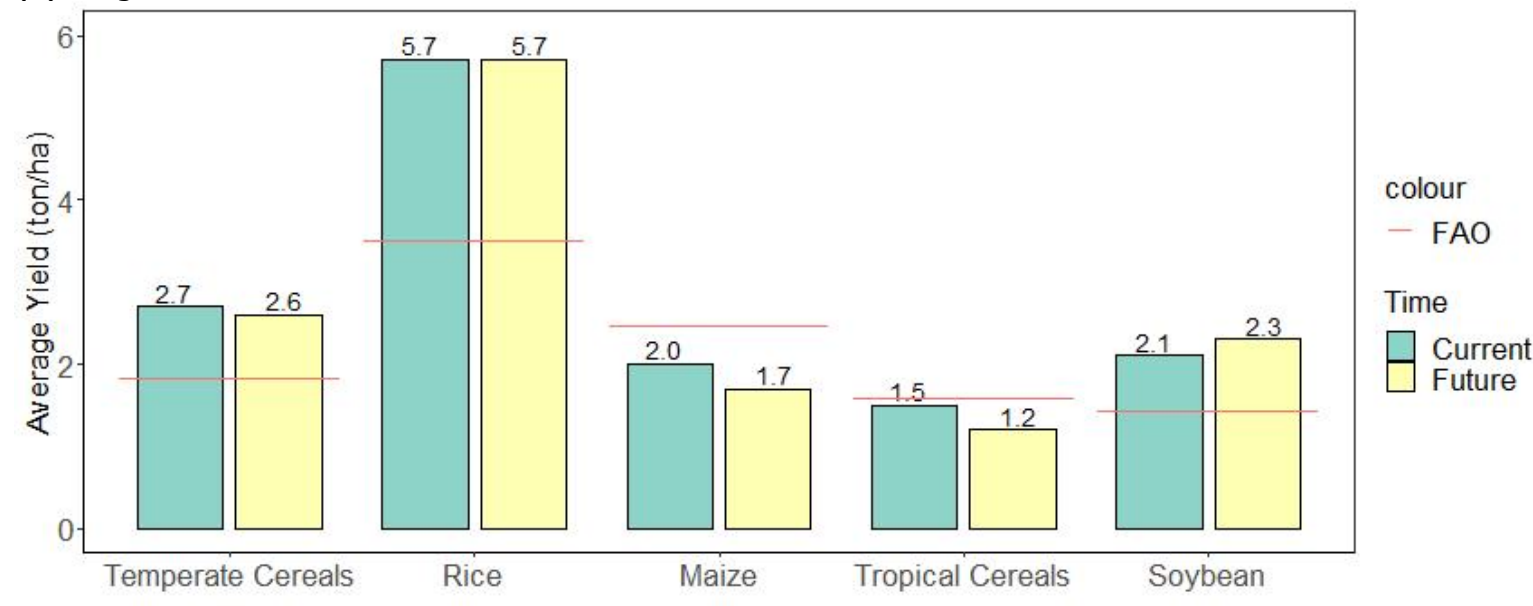

Figure 3 Average simulated yields by LPJmL of Temperate Cereals, Rice, Maize, Tropical Cereals, and Soybean in the current climate (1986-2016) (scenario B) and the future climate (2036-2065) (scenario $C$ ) in Ethiopia, for rainfed (a) and irrigated (b) conditions. The red lines indicate average yields in Ethiopia based on FAOSTAT data between 2000 and 2019.

Table 4 Percentage change in average yield $(\Delta Y)$ for cereal and soybean CFTs from the current climate (1986-2016) (scenario B) to the future climate (2036-2065) (scenario C) under rainfed and irrigated conditions.

\begin{tabular}{lrr} 
& $\begin{array}{c}\Delta \text { from current to } \\
\text { future }(\%)\end{array}$ & Rainfed \\
Temperate Cereals & -3 & -4 \\
\hline Rice & 35 & -15 \\
\hline Maize & -11 & -15 \\
\hline Tropical Cereals & -17 & -20 \\
\hline Soybean & 0 & 10 \\
\hline
\end{tabular}


Table 5 Average of simulated number of growing days given the current (1986-2016) (scenario B) and future (2036-2065) (scenario C) climate for cereal and soybean CFTs.

\begin{tabular}{|c|c|c|c|c|}
\hline & \multicolumn{2}{|c|}{ Rainfed } & \multicolumn{2}{|c|}{ Irrigated } \\
\hline & Current & Future & Current & Future \\
\hline Temperate Cereals & 155 & 143 & 135 & 127 \\
\hline Maize & 185 & 160 & 172 & 149 \\
\hline Tropical Cereals & 134 & 118 & 128 & 109 \\
\hline
\end{tabular}

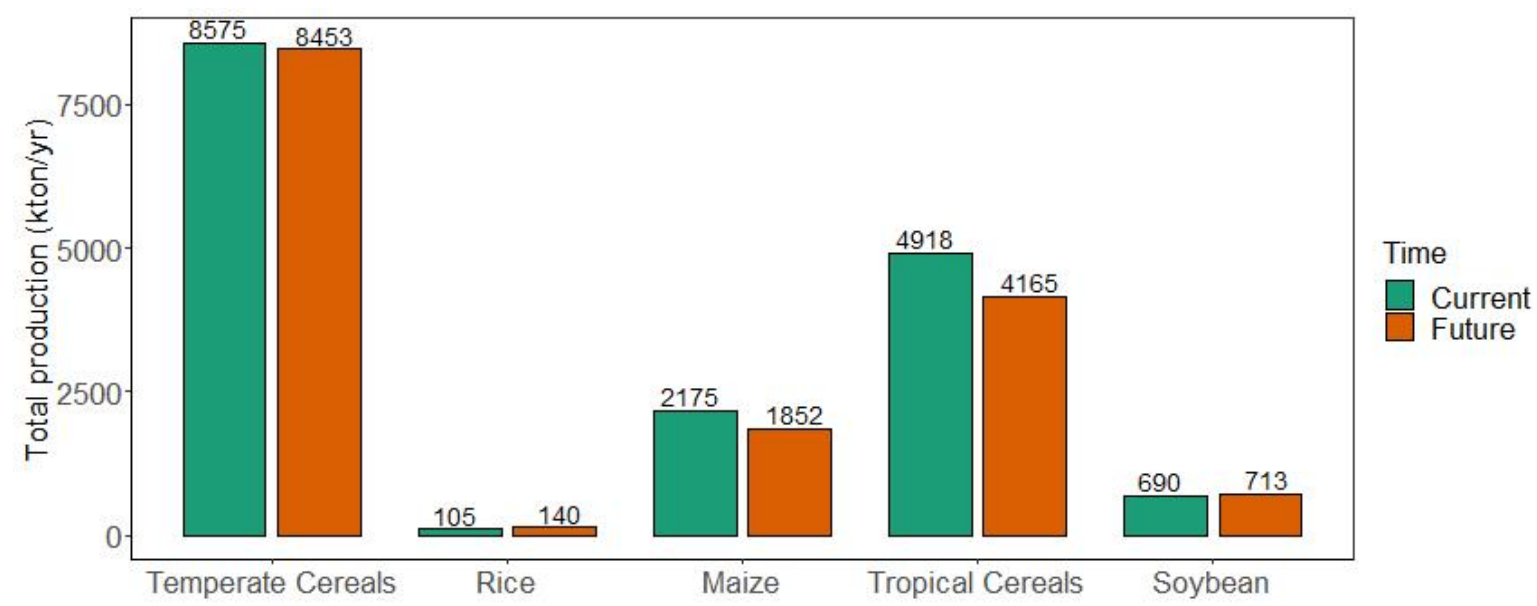

Figure 4 Total production (kton/year) of each CFT with current (1986-2016) (scenario B) and future (2036-2065) (scenario C) climate, estimated based on simulated yields and physical CFT areas.

\subsubsection{Precipitation Deficit/Surplus}

To understand the effect that the diet shift from cereals to soybean would have on their water availability, we examined the difference in annual precipitation and evapotranspiration by cereals and soybean. The difference between the two is shown geographically in Figure 5, and country averages are reported in Table 6 . Some practical points to note:

- In Figure 5, there are some white cells that fell out of the color scale of the map, as the maximum end of the color range was set too low. It is probable that some red cells were therefore lost, and that the maps show a slight under-representation of the precipitation deficit.

In Table 6, the annual precipitation is slightly different between scenario A and B, even though both are simulated with the same climate. The annual precipitation on cereals and soy at the national level is computed as a weighted average, based on cell values with the total area of cereal and soy of each cell as weights. The net reduction in cereal plus soy area due to the shift from cereals to soy, therefore has slightly affected the average precipitation.

Based on the information in the figures below, we can conclude the following points:

- The diet shift from cereals to soybean has caused minimal changes in the precipitation deficit/surplus. A slight increase in both transpiration and evaporation could be caused by the lower total area for cereal and soy (see above) or possibly by a higher ET of soy than of cereals, which still need to be checked.

- Towards the future, the precipitation deficit is projected to decrease and even turn into a surplus. Although this is a positive outcome, it is not completely clear yet what the underlying reasons are for this result. The following points can be noted:

- Precipitation is projected to increase, which could partly explain the precipitation surplus. However, increased precipitation generally also leads to increased transpiration whenever water is limiting. For cereals and soy in Ethiopia, it is unclear whether water is a limiting factor, as the 
lower irrigated yields compared to precipitation yields (Figure 3) seem to indicate that water is not limiting, while the precipitation deficits in Table 6 seem to indicate the opposite.

- Transpiration is projected to decrease in the future climate, despite increasing precipitation and temperature (Table 6). This could be explained by the shorter growing period of the cereals, which would cause less transpiration. However, the relative decrease in transpiration is much larger than the relative decrease in growth duration, which is still not well understood.

- Evaporation is also projected to decrease, but it is still unclear why this is the case. A shorter growing season would be expected to lead to more evaporation outside of the growing season. Moreover, a higher temperature would also be expected to increase evaporation.

- Overall, we can conclude that the dietary shift would not lead to major changes in water availability for the two CFT's (scenario A versus B), and that the shift would not suffer from higher precipitation deficits with the future climate (scenario B versus C). However, it is still necessary to further analyse model outcomes to better understand these results.

Table 6 For each scenario, the average actual evapotranspiration (ET), transpiration, and evaporation of cereals and soy per year, and the average annual precipitation $(P)$ and temperature in cells with either cereals, soy, or both. Averages are weighted for cell area of each crop. The difference between the annual $P$ and ET (i.e. the precipitation deficit or surplus on cereals and soy) is indicated in the bottom row. Current and future situations were averaged over 1986 to 2016 and 2036 to 2065 respectively.

\begin{tabular}{|c|c|c|c|}
\hline & $\begin{array}{l}\text { Scenario A: } \\
\text { Current Climate }\end{array}$ & $\begin{array}{c}\text { Scenario B: } \\
\text { Current Climate + } \\
\text { Protein Shift }\end{array}$ & $\begin{array}{c}\text { Scenario C: } \\
\text { Future Climate + } \\
\text { Protein Shift }\end{array}$ \\
\hline Annual Evapotranspiration (mm/y) & 1369 & 1386 & 1142 \\
\hline Annual Transpiration (mm/y) & 580 & 590 & 418 \\
\hline Annual Precipitation (mm/y) & 1172 & 1167 & 1226 \\
\hline Annual P - ET (mm/y) & -197 & -219 & 84 \\
\hline
\end{tabular}


Scenario A:

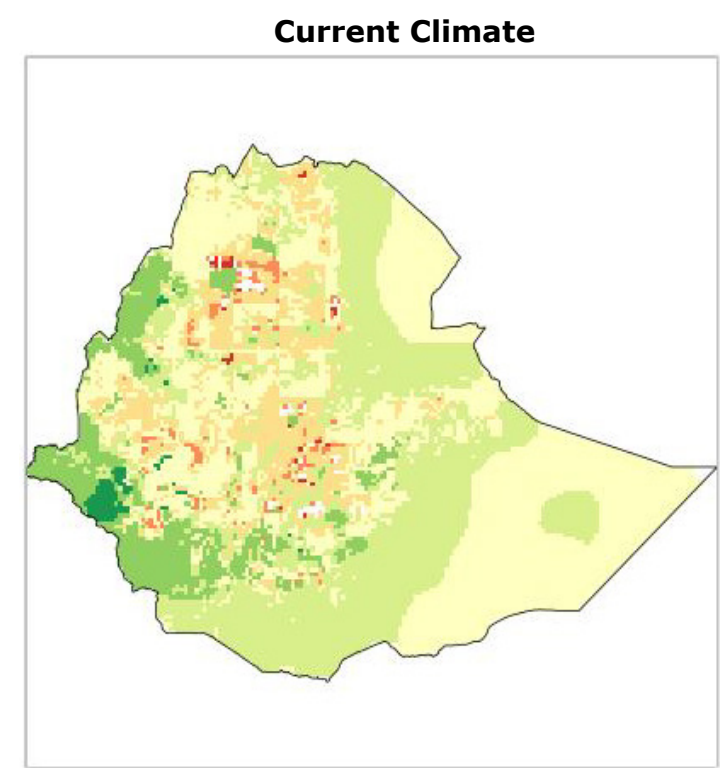

Scenario B:

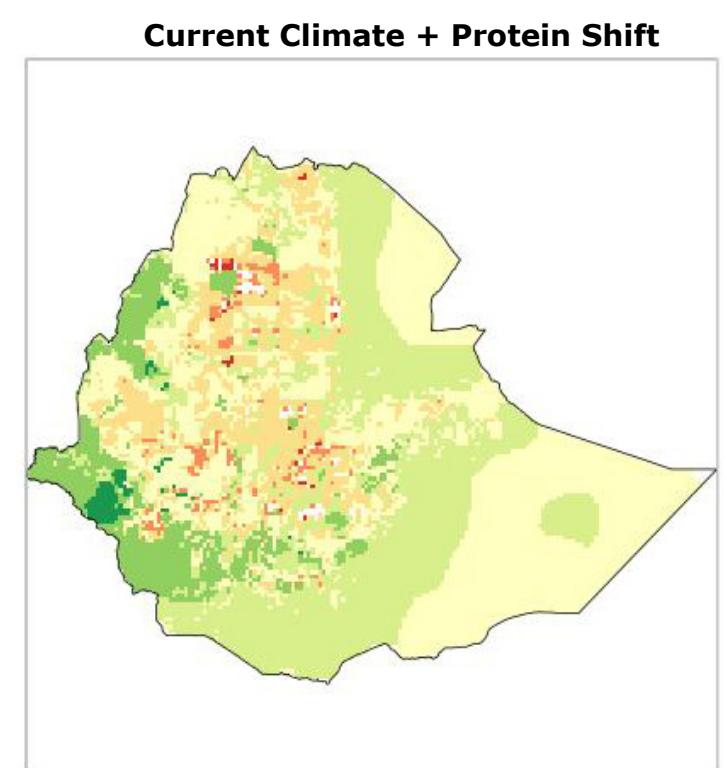

Scenario C:

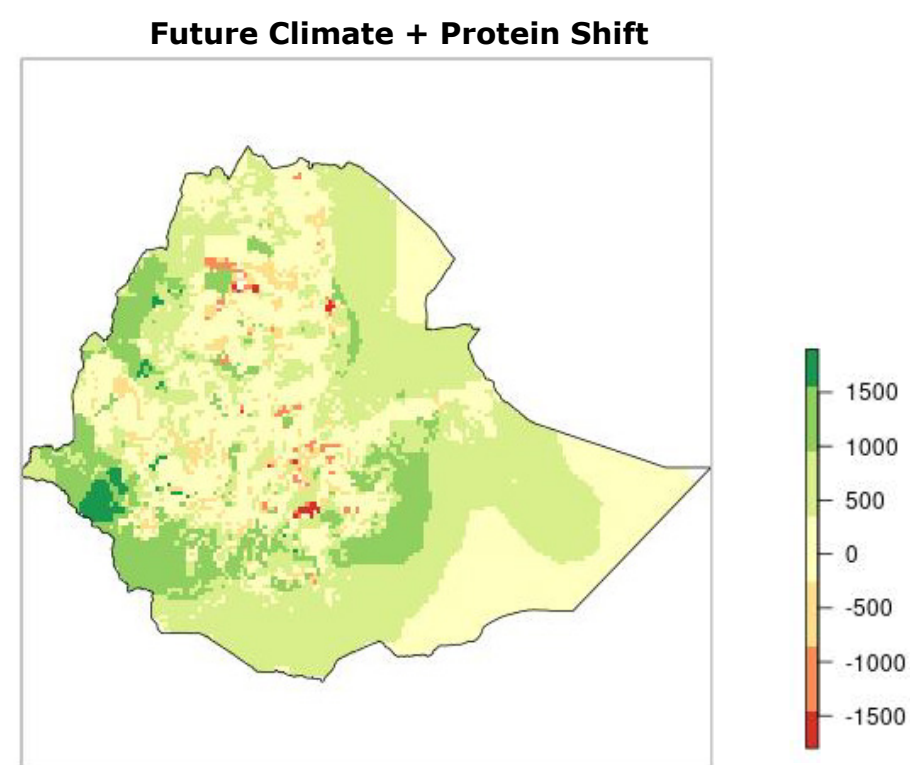

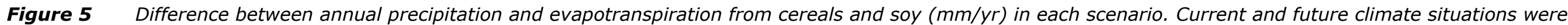
averaged over 1986 to 2016 and 2036 to 2065 respectively. 


\subsubsection{Irrigation Demand}

To further understand the effect of the diet shift from cereals to soybean the annual irrigation was also analysed (Figure 6). The following points can be concluded:

- The diet shift leads to a slight decrease in annual irrigation volume, from 139 to 137 million m3. The decrease is caused by:

- The net decrease in crop area, including irrigated area, as a result of the shift.

- The fact that soybean has a smaller irrigated area fraction than the cereals (Table 3 ) which means that in the new soybean area, a smaller fraction is irrigated than of the cereal area that was there before.

- Towards the future, irrigation demand would decrease (from 137 to 114 million $\mathrm{m} 3$ ). This is in line with the values in Table 6, and is therefore likely caused by the higher precipitation and lower evapotranspiration with the future climate. However, these results still need further investigation.

- Overall, the diet shift does not seem to lead to large changes in irrigation demand, and seems resilient to changes in climate as projected by this specific climate scenario.

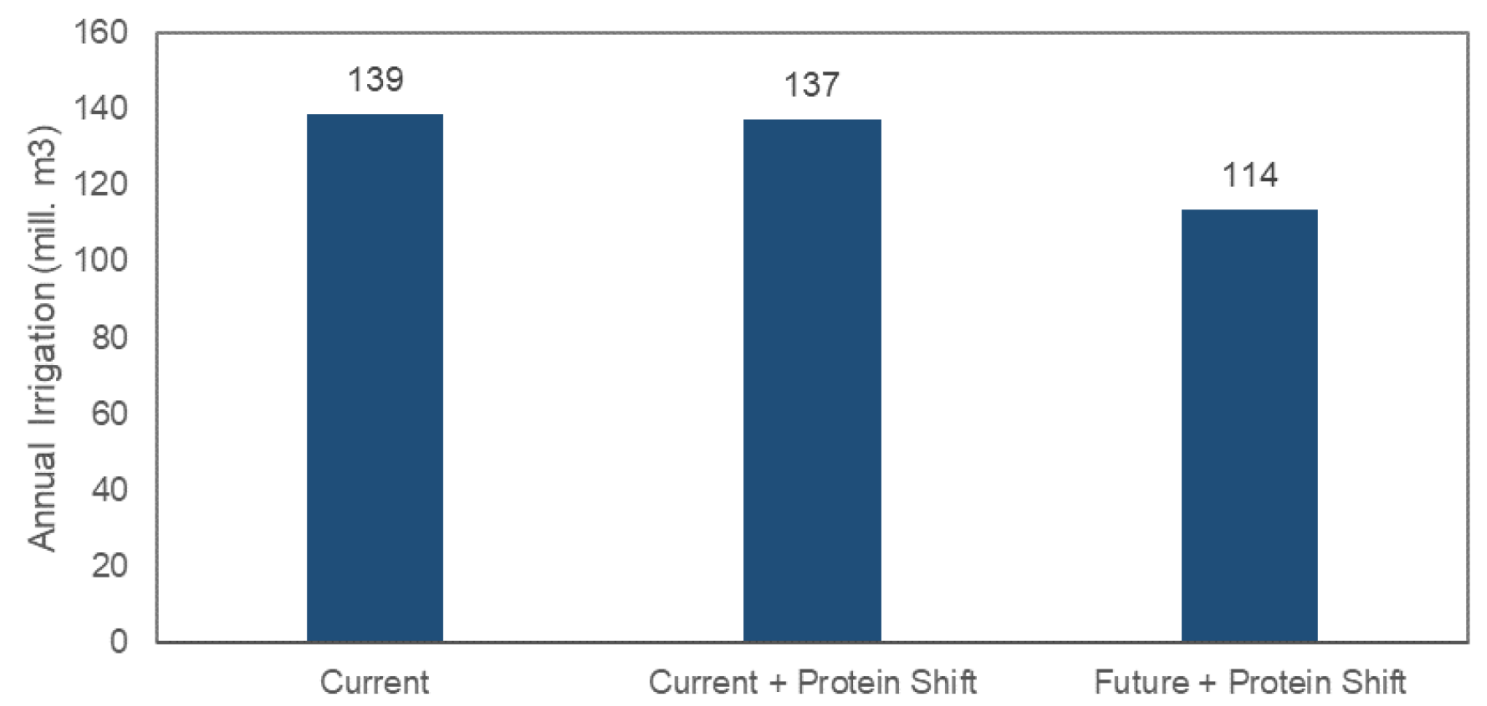

Figure 6 Average total annual irrigation volume for all CFTs across Ethiopia in each scenario. Averages were computed over 1986-2016 and 2036-2065 for the current and future climate respectively.

\subsection{Results for Multiple Scales}

\subsubsection{Yields and Production}

To investigate the potential food production of Ethiopia under rainfed conditions, we simulated scenarios $A$ and $D$, modelling Ethiopia's cropland under the current climate at the actual (scenario $A$ ) and rainfed potential (scenario $D$ ) level respectively. In both situations land use was derived from MapSpam. The average yields at both productivity levels are reported in Figure 7, and the corresponding total production in Figure 8. The number of growing days for both scenarios are reported in Table 7. Note that as LPJmL simulates only a single growing cycle per crop, all figures refer only the main cropping cycle of each crop. Some practical points to note:

- The FAO yield of sugarcane is 64 ton/ha, which was left out of Figure 7 as it is in a different order of magnitude than the other actual, potential, and FAO yields, and would therefore dwarf all other values. The large difference between the FAO and simulated sugarcane yields needs to be investigated.

- As in Figure 3, the current yields (green bars) should be close to the FAO yields, which is the case for all CFTs except Temperate Cereals. The reason for this is unclear and needs further investigation.

- Rainfed potential yield levels still need to be checked with respect to their reliability 
The following points can be concluded from the results:

- Ethiopia has the potential to greatly increase its actual yields and thereby its food production by intensifying its crop production (e.g. by higher nutrient inputs). Yields in the main cycle could be increased by a factor three for soybean up to a factor nine for other pulses and rapeseed. This could improve Ethiopia's food security without the need for agricultural land expansion.

- The number of growing days at the current and rainfed potential level are exactly the same for all CFTs. Higher yields in the simulation of scenario D are a result of assuming a maximum LAI of 7 for all CFT's and is not related to growing season length.

- According to our simulation, the main CFT contributors to a greater food production through intensification in Ethiopia would be temperate cereals (mostly wheat), maize, tropical cereals (teff, millet, and sorghum), and pulses, as they dominate current land use (Figure 8). We still need to simulate starchy roots (tropical and temperate) and sunflower, however their physical area is too small to contribute significantly.

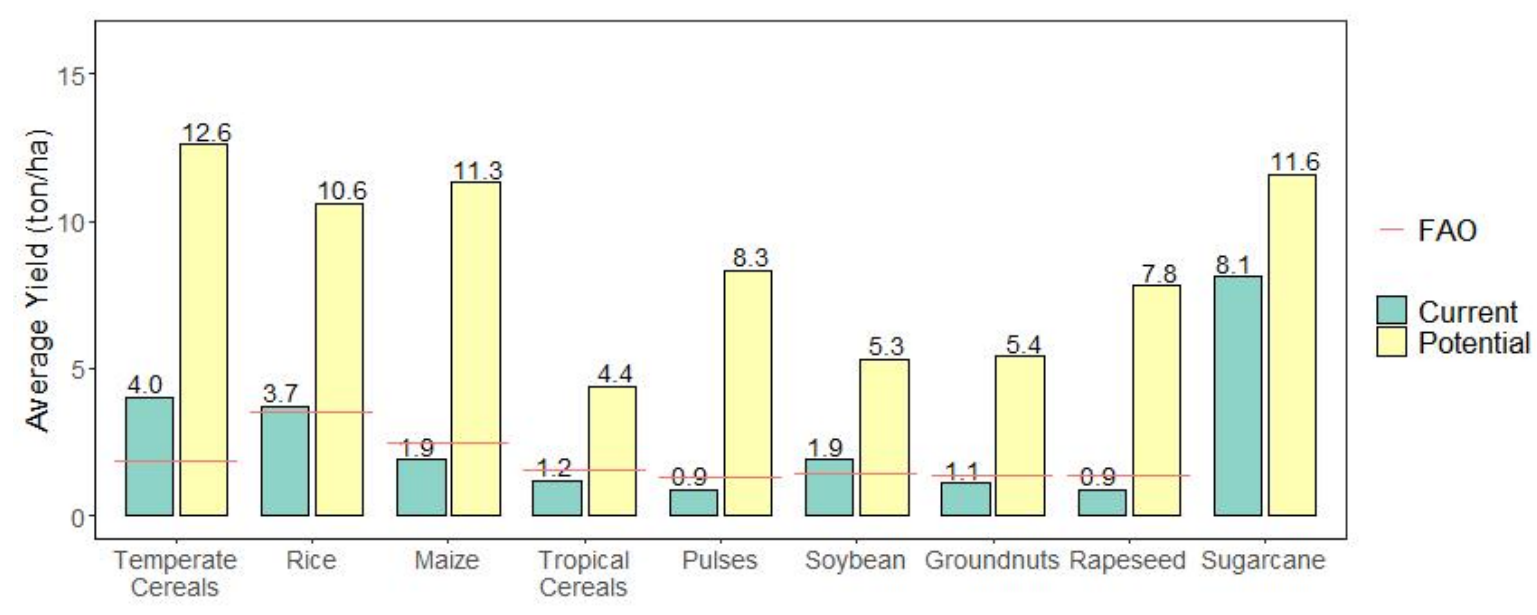

Figure 7 Average simulated rainfed yields at the current (i.e. actual) production intensity (scenario A) and at the rainfed potential production intensity (scenario D) in the main cropping cycle under the current (1986 to 2016) climate conditions in Ethiopia for each Crop Functional Type (CFT). Average FAO yield over the period of 2000 to 2016 is indicated by the red horizontal lines.

Table 7 Average simulated number of growing days for each Crop Functional Type (CFT) at the current production intensity (scenario A) and at the rainfed potential production intensity (scenario $D$ ). Averages for the years 1986 to 2016.

\begin{tabular}{ll} 
CFT & Growing days \\
Temperate Cereals & 155 \\
\hline Rice & 177 \\
\hline Maize & 183 \\
\hline Tropical Cereals & 134 \\
\hline Pulses & 113 \\
\hline Soybean & 101 \\
\hline Groundnuts & 192 \\
\hline Rapeseed & 156 \\
\hline Sugarcane & 351 \\
\hline
\end{tabular}




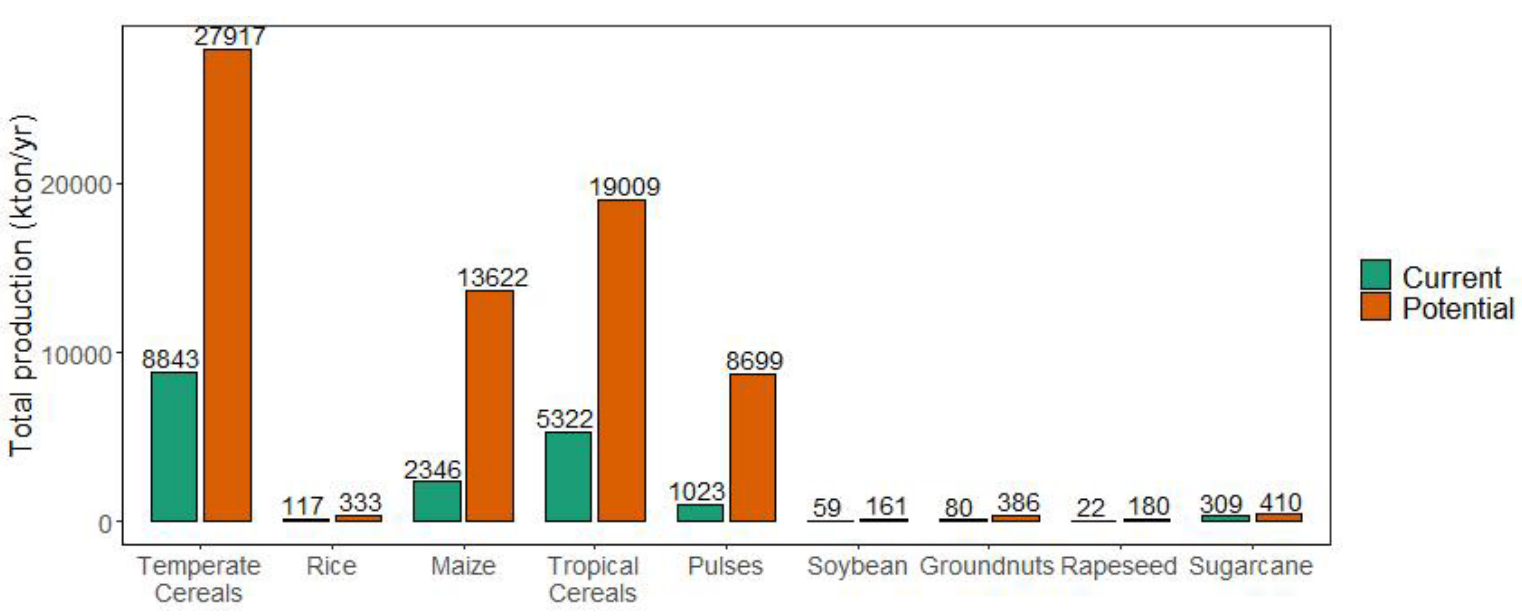

Figure 8 Average production at the current (i.e. actual) production intensity (scenario A) and at the rainfed potential production intensity (scenario D) under the current (1986 to 2016) climate conditions in Ethiopia. Production was estimated based on simulated yields in the main cropping cycle and physical areas of each Crop Functional Type.

\subsubsection{Precipitation Deficit}

To investigate the effect that producing at the rainfed potential (i.e. water limited) level would have on Ethiopia's water balance, we examined the effect on the deficit between precipitation and crop evapotranspiration Table 8. A practical point to note:

- Table 8 includes only the ET of the cereal and soybean CFTs, because the same analysis was used as for the project Soy10. In future, the ET of all CFTs will be examined, but for now we assume that these figures already give an impression of the precipitation deficit on cropland, as the cereal and soybean crops cover the majority of the total physical cropping area in Ethiopia (65\%; see Table 3 ).

From the simulation results, we can conclude the following points:

- A higher production intensity would lead to a greater transpiration by the crops, as a result of greater biomass production and higher leaf area index (LAI).

- On the other hand, soil evaporation from croplands would be reduced due to the smaller area left uncovered by the crop, which negatively affects soil evaporation.

- The increase in transpiration outweighs the decrease in evaporation, leading to a net increase in evapotranspiration going from 1369 to $1496 \mathrm{~mm} / \mathrm{yr}$ (+ $127 \mathrm{~mm} / \mathrm{y})$. Overall, we can therefore conclude that a production intensification would utilize a larger share of Ethiopia's water resources available at croplands than the current production intensity. However, the water use efficiency would improve at this higher production intensity and the amount of water required per $\mathrm{kg}$ of food would probably decrease as a result of intensification.

- Due to the higher ET, the precipitation deficit on croplands increases by a factor of around 1.6. As already noted above, these deficit values need to be further investigated.

Table 8 For each scenario, the average actual evapotranspiration (ET), transpiration, and evaporation of cereals and soy per year, and the average annual precipitation $(P)$ and temperature in cells with cereals or soy. Averages are weighted for cell area of each crop. The difference between the annual ET and P (i.e. the precipitation deficit or surplus on cereals and soy) is indicated in the bottom row. Current situations were averaged over 1986 to 2016.

\begin{tabular}{lrr} 
& \multicolumn{2}{c}{$\begin{array}{c}\text { Scenario A: } \\
\text { Current Production Intensity }\end{array}$} \\
& 19 & Rainfed Potential Production Intensity \\
Average Temperature $\left({ }^{\circ} \mathrm{C}\right)$ & 1369 & 19 \\
\hline Annual Evapotranspiration $(\mathrm{mm} / \mathrm{y})$ & 580 & 1496 \\
\hline Annual Transpiration $(\mathrm{mm} / \mathrm{y})$ & 789 & 1212 \\
\hline Annual Evaporation $(\mathrm{mm} / \mathrm{y})$ & 1172 & 284 \\
\hline Annual Precipitation $(\mathrm{mm} / \mathrm{y})$ & -197 & 1172 \\
\hline Annual P - ET $(\mathrm{mm} / \mathrm{y})$ & & -324 \\
\hline
\end{tabular}




\section{$7 \quad$ Conclusions and Further Research}

\subsection{Conclusions for Soy10}

- A diet shift replacing $10 \%$ of cereal food protein by soybean protein could free up around 238000 ha of physical area of cropland in Ethiopia, which is around $2 \%$ of the country's total cropland area. The higher protein content of soybean compared to cereals leads to a higher protein yield per hectare, therefore allowing for the production of the same amount of proteins from less land.

- Cereal yields appear to be slightly negatively impacted by the climate scenario selected for this study, while soybean yields are not impacted. It can be concluded that the selected future climate would not significantly alter the results of the shift from cereals towards soybean production as compared to the current climate.

- The dietary shift would also not lead to major changes in water availability for cereals and soybean, and the precipitation deficit of the modified land use situation due to the shift would improve with the selected climate scenario modified. However, it is still necessary to further analyse model outcomes on water balances to better understand these results.

\subsection{Conclusions for Multiple Scales}

- Ethiopia has the potential to greatly increase its actual yields and thereby its food production by intensifying its crop production. Yields in the main crop cycle could be increased by a factor three up to a factor nine depending on the crop. Such a productivity increase improves Ethiopia's food production without the need for agricultural land expansion.

- A productivity increase would lead to an increased transpiration and decreased evaporation, with a net increase in evapotranspiration. We can therefore conclude that a production intensification would use a greater portion of Ethiopia's water resources on cropland than the current production intensity.

- However, as yields would increase more steeply than the ET, the higher production intensity would likely lead to a greater water use efficiency. This still needs to be further verified.

\subsection{Future Research}

\subsubsection{General Points to Address}

In order to continue future analyses for Ethiopia with LPJmL there are some practical points that need to be addressed, which have been mentioned throughout the report. They are summarized below:

- The MapSPAM crops potato, sweet potato, and yams needs to be regrouped into the CFTs Temperate Roots and Tropical Roots, as they are now in the CFT Others. The calibration needs to be performed again with this new CFT grouping as well as with sunflower.

- The average FAO yields were calculated using the production volumes of the crops in each CFT as weights. This can results in a slight misrepresentation of the actual yields. The FAO average yields need to be recalculated as the total production of all crops in the CFT divided by the total harvested area of all crops in the CFT. The newly calculated FAO yields should be used in the new calibration.

- The differences between the simulated and FAO yield of the CFTs Temperate Cereals and Sugarcane need to be explained/solved.

- The dynamics in the water balance of LPJmL, including the interaction between precipitation, evaporation, and transpiration, needs to be further studied to better understand the precipitation surplus in the current and future scenarios (Table 6).

- We need to develop a solution for the difference between physical and harvested areas with respect to production and ET, where LPJmL only simulates one cycle per crop per year. Also, pasture productivity and the water balance of the whole country needs to be investigated for an analysis of water flows from Ethiopia towards its neighbours. 


\subsubsection{Further Research for Soy10}

For the project Soy10, the following points need attention before future explorations can be done:

- The adjusted land use maps need to be re-examined to understand why the area of pulses was increased. This is the result of a mistake somewhere in the analysis and should be corrected (Table 3).

- The evapotranspiration (ET) of the individual CFTs needs to be examined. An ET that is higher for the CFT soybean than of the cereal CFTs could explain the slightly higher precipitation deficit in the modified land use with more soybean (Table 6).

Aside from these practical points, the following explorations would shed more light on the possible impact of a shift in protein source:

- Thus far, the averages of yields, growing days, and water balance components were computed for all cells where either a cereal or soybean was growing. However, the shift of cereal area to soy area was done only in cells where there was already soy growing, to ensure that soy actually could grow in the areas where the increased area was placed. It would therefore be informative to analyse the differences between the scenarios only in the cells where the shift from cereals to soybean took place, rather than to include all cells where cereals were grown but not soybean. This would give a more realistic comparison of how the crops perform relative to each other specifically in the relevant areas.

- The current analyses were done for a scenario where $10 \%$ of the cereal protein source was replaced by soybean. It would be informative to explore the impact of a greater replacement of for example $50 \%$ on land use and other explored variables. This could open up a lot more land for other purposes. However, this exploration should also involve the impact that such a shift would have on the overall diet, as other macro and micronutrient demands also still need to be covered.

\subsubsection{Further Research for Multiple Scales}

For the project Multiple Scales, the following points need further attention before future explorations can be done:

- The analysis on precipitation deficit (Table 8) currently includes the ET of only cereals and soybean, while the project Multiple Scales focusses on all crops and grasslands in use by livestock. The ET should be recalculated for all CFTs. It is also necessary to determine whether the ET of the CFT Others should also be included in the crop ET, as it is currently simulated as grassland.

Aside from this practical point, the following issues can be taken into account

- The rainfed potential production was estimated with LPJmL under the current conditions, but the project also aims to model potential production under rainfed conditions in the future, to better understand the country's resilience towards climate change and ability to feed its growing population.

- The project also intends to simulate potential irrigated yields under the current and future climate, to investigate to what extent irrigation can improve food security, and to understand the impact that widespread irrigation would have on the country's water balance.

- Potential yields and national production totals will be compared with various demands for food in the country, based on different diet options in future situations, viz. 2050. They will be used to check whether the demands can be produced in Ethiopia or whether imports are needed to contribute to food security and zero hunger in Ethiopia. Also, the required nutrient inputs will be estimated from the yield potentials. This will connect the results at grid level from LPJmL to the national-scale model BIOSPACS, where human diet, food demands and agricultural production and inputs are linked.

- It is also a goal to generate yield potential maps of all CFTs in the current and future climate (either with or without irrigation), that can be used as input for the model MagnetGrid as crop suitability maps.

- The LPJmL simulations currently only model crops, but not managed grassland for livestock production. As Ethiopia has a relatively large livestock sector, managed grassland is an important crop to determine the country's potential food production. In future this should be explored how this crop can be included in the LPJmL simulations.

- Finally, this version of LPJmL can only model a single cropping season for each CFT. However, Ethiopia has multiple cropping seasons and it would therefore be of much added value to the estimation of the food production potential and the corresponding water balance to also include at least a second growing season. 


\section{References}

Bondeau, A., Smith, P. C., Zaehle, S., Schaphoff, S., Lucht, W., Cramer, W., . . Reichstein, M. (2007). Modelling the role of agriculture for the 20th century global terrestrial carbon balance. Global Change Biology, 13(3), 679-706.

CSA. (2019). Agricultural Sample Survey 2019/20 - Volume I: Report on Area and Production of Major Crops Retrieved from https://www.statsethiopia.gov.et/wp-content/uploads/2020/04/Report-onArea-and-production-of-major-crops-2012-E.C-Meher-season.pdf

Fader, M., Rost, S., Müller, C., Bondeau, A., \& Gerten, D. (2010). Virtual water content of temperate cereals and maize: Present and potential future patterns. Journal of Hydrology, 384(3-4), 218-231.

FAOSTAT. (2021). Crops and livestock products. Retrieved from: http://www.fao.org/faostat/en/\#data/QCL

Fischer, G., F., Nachtergaele, S., Prieler, H. T., van Velthuizen, L., Verelst, \& Wiberg, D. (2008). Global Agro-ecological Zones Assessment for Agriculture (GAEZ 2008). Retrieved from: http://www.fao.org/soils-portal/data-hub/soil-maps-and-databases/harmonized-world-soildatabase-v12/en/

GYGA. Global Yield Gap and Water Productivity Atlas. Retrieved from: https://www.yieldgap.org/

IFPRI. (2020). Spatially-Disaggregated Crop Production Statistics Data in Africa South of the Sahara for 2017. Retrieved from: https://www.mapspam.info/data/

ISIMIP. (2021). ISIMIP3 Protocol. Retrieved from https://www.isimip.org/protocol/3/

Jones, P., \& Harris, I. (2013). CRU TS3. 21: Climatic Research Unit (CRU) Time-Series (TS) version 3.21 of high resolution gridded data of month-by-month variation in climate (Jan. 1901Dec. 2012). NCAS British Atmospheric Data Centre.

Lange, S. (2019). WFDE5 over land merged with ERA5 over the ocean (W5E5). V. 1.0.

Lehner, B., \& Döll, P. (2004). Development and validation of a global database of lakes, reservoirs and wetlands. Journal of Hydrology, 296(1-4), 1-22.

Lehner, B., Liermann, C. R., Revenga, C., Vörösmarty, C., Fekete, B., Crouzet, P., . . . Wisser., D. (2011). High-resolution mapping of the world's reservoirs and dams for sustainable river-flow management. Retrieved from: http://globaldamwatch.org/grand/

Lehner, B., Verdin, K., \& Jarvis, A. (2008). New global hydrography derived from spaceborne elevation data. Retrieved from: https://www.hydrosheds.org/page/availability

NaturalEarth. (2021). 1:10 Cultural Vectors. Retrieved from: http://www.naturalearthdata.com/downloads/10m-cultural-vectors/

Ogutu, G. E., Franssen, W. H., Supit, I., Omondi, P., \& Hutjes, R. W. (2018). Probabilistic maize yield prediction over East Africa using dynamic ensemble seasonal climate forecasts. Agricultural and forest meteorology, 250, 243-261.

Paff, K., \& Asseng, S. (2019). A crop simulation model for tef (Eragrostis tef (Zucc.) Trotter). Agronomy, 9(12), 817.

Paff, K. E. (2018). Food Security in Ethiopia: Developing a Dynamic Crop Simulation Model for Eragrostis tef (Zucc.) Trotter. University of Florida,

Schaphoff, S., von Bloh, W., Rammig, A., Thonicke, K., Biemans, H., Forkel, M., ... Knauer, J. (2018). LPJmL4-a dynamic global vegetation model with managed land-Part 1: Model description. Geoscientific Model Development, 11(4), 1343-1375.

Taffesse, A. S., Dorosh, P. A., \& Asrat, S. (2012). Crop production in Ethiopia: Regional patterns and trends: Summary of ESSP working paper 16. Retrieved from

WorldBank. (2021). Climate Data - Projections for Ethiopia. Retrieved from https://climateknowledgeportal.worldbank.org/country/ethiopia/climate-data-projections 


\author{
Links \\ LPJmL Wiki - Inputs: https://github.com/PIK-LPJmL/LPJmL/wiki/Input \\ LPJmL Wiki - River routing: https://github.com/PIK-LPJmL/LPJmL/wiki/River_routing \\ LPJmL Wiki - Dams and reservoirs: https://github.com/PIK-LPJmL/LPJmL/wiki/Dams_and_reservoirs \\ LPJmL Wiki - Crop Functional Types: https://github.com/PIK-LPJmL/LPJmL/wiki/Crop_functional_types \\ LPJmL Wiki - Sowing Dates: https://github.com/PIK-LPJmL/LPJmL/wiki/Sowing_dates \\ LPJmL Wiki - How To: https://github.com/PIK-LPJmL/LPJmL/wiki/HowTo \\ MIRCA2000 portal: https://www.uni-frankfurt.de/45218031/Data_download_center_for_MIRCA2000 \\ PIK ESGF node: https://esg.pik-potsdam.de/search/isimip/ \\ LPJmL github repository: https://github.com/PIK-LPJmL/LPJmL
}




\section{Annex 1 Supplementary Material}

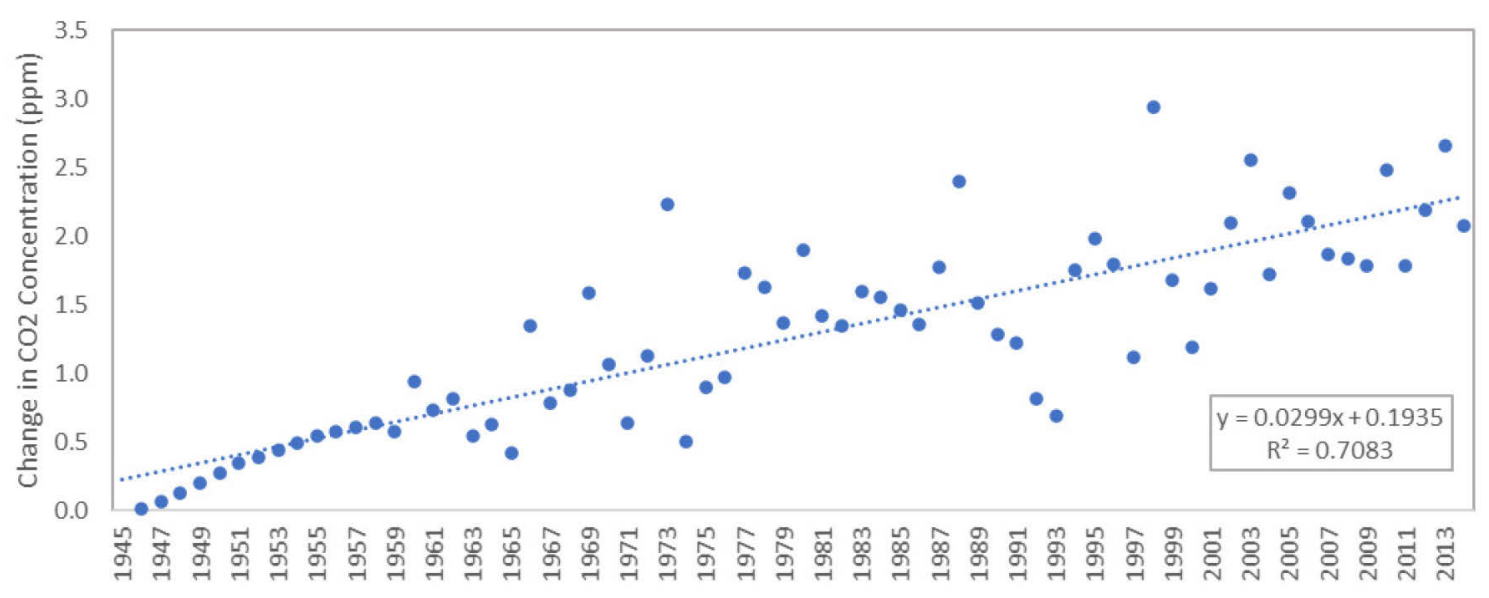

Figure 9 Scatterplot and regression of the change in average CO2 concentration in the atmosphere (ppm) relative to the previous year from 1945 to 2014. Source: Wageningen Environmental Research.

Table 9 Crops in MapSPAM dataset as grouped into crop functional types (CFTs) of LPJmL according to LPJmL Wiki - Crop Functional Types.

\begin{tabular}{|c|c|}
\hline MapSPAM crop & Crop Functional Type (CFT) in LPJmL \\
\hline wheat & Temperate Cereals \\
\hline barley & Temperate Cereals \\
\hline maize & Maize \\
\hline pearl millet & Tropical Cereals \\
\hline sorghum & Tropical Cereals \\
\hline other cereals & Tropical Cereals \\
\hline bean & Pulses \\
\hline chickpea & Pulses \\
\hline other pulses & Pulses \\
\hline potato & Others \\
\hline sugar beet & Temperate Roots \\
\hline sweet potato & Others \\
\hline yams & Others \\
\hline cassava & Tropical Roots \\
\hline other roots & Others \\
\hline sunflower & Sunflower \\
\hline soybean & Soybean \\
\hline sesame seed & Others \\
\hline other oil crops & Others \\
\hline cotton & Others \\
\hline
\end{tabular}




\begin{tabular}{ll} 
MapSPAM crop & Crop Functional Type (CFT) in LPJML \\
\hline other fibre crops & Others \\
\hline arabica coffee & Others \\
\hline robusta coffee & Others \\
\hline cocoa & Others \\
\hline tea & Others \\
\hline tobacco & Others \\
\hline banana & Others \\
\hline plantain & Others \\
\hline tropical fruit & Others \\
\hline temperate fruit & Others \\
\hline vegetables & Others \\
\hline rest of crops & Others
\end{tabular}

Table 10 Grouping of crops produced in Ethiopia as reported in FAOSTAT into LPJmL's Crop Functional Types (CFTs). * Should have been categorized into 'Temperate Roots'. ** Should have been categorized into "Tropical Roots". *** Should have been categorized into 'Others', as it is categorized as a vegetable.

\begin{tabular}{|c|c|c|c|}
\hline FAOSTAT crop & CFT & FAOSTAT crop & CFT \\
\hline Barley & Temperate Cereals & Maté & Others \\
\hline Wheat & Temperate Cereals & Mustard seed & Others \\
\hline Rice, paddy & Rice & Nutmeg, mace and cardamoms & Others \\
\hline Maize & Maize & Peaches and nectarines & Others \\
\hline Cereals nes & Tropical Cereals & Safflower seed & Others \\
\hline Oats & Tropical Cereals & Sisal & Others \\
\hline Millet & Tropical Cereals & Spices nes & Others \\
\hline Sorghum & Tropical Cereals & Sesame seed & Others \\
\hline Beans, dry & Pulses & Tea & Others \\
\hline Chick peas & Pulses & Tobacco, unmanufactured & Others \\
\hline Cow peas, dry & Pulses & Avocados & Others \\
\hline Lentils & Pulses & Bananas & Others \\
\hline Beans, green & Pulses*** & Fruit, citrus nes & Others \\
\hline Broad beans, horse beans, dry & Pulses*** & Fruit, fresh nes & Others \\
\hline Peas, dry & Pulses & Fruit, tropical fresh nes & Others \\
\hline Peas, green & Pulses*** & Lemons and limes & Others \\
\hline Pulses nes & Pulses & Mangoes, mangosteens, guavas & Others \\
\hline Potatoes & Others* & Melonseed & Others \\
\hline Roots and tubers nes & Others** & Oranges & Others \\
\hline Sweet potatoes & Others** & Papayas & Others \\
\hline Yams & Others** & Pineapples & Others \\
\hline Sunflower seed & Sunflower & $\begin{array}{l}\text { Tangerines, mandarins, clementines, } \\
\text { satsumas }\end{array}$ & Others \\
\hline Soybeans & Soybean & Cabbages and other brassicas & Others \\
\hline Groundnuts, with shell & Groundnuts & Carrots and turnips & Others \\
\hline Rapeseed & Rapeseed & Chillies and peppers, dry & Others \\
\hline Sugar cane & Sugarcane & Chillies and peppers, green & Others \\
\hline Coffee, green & Others & Cucumbers and gherkins & Others \\
\hline Seed cotton & Others & Garlic & Others \\
\hline Bastfibres, other & Others & Leeks, other alliaceous vegetables & Others \\
\hline Fibre crops nes & Others & Lettuce and chicory & Others \\
\hline Castor oil seed & Others & Onions, dry & Others \\
\hline Linseed & Others & Onions, shallots, green & Others \\
\hline Nuts nes & Others & Pepper (piper spp.) & Others \\
\hline Oilseeds nes & Others & Tomatoes & Others \\
\hline Anise, badian, fennel, coriander & Others & Vegetables, fresh nes & Others \\
\hline Ginger & Others & Vegetables, leguminous nes & Others \\
\hline Grapes & Others & Vetches & Others \\
\hline Hops & Others & & \\
\hline
\end{tabular}




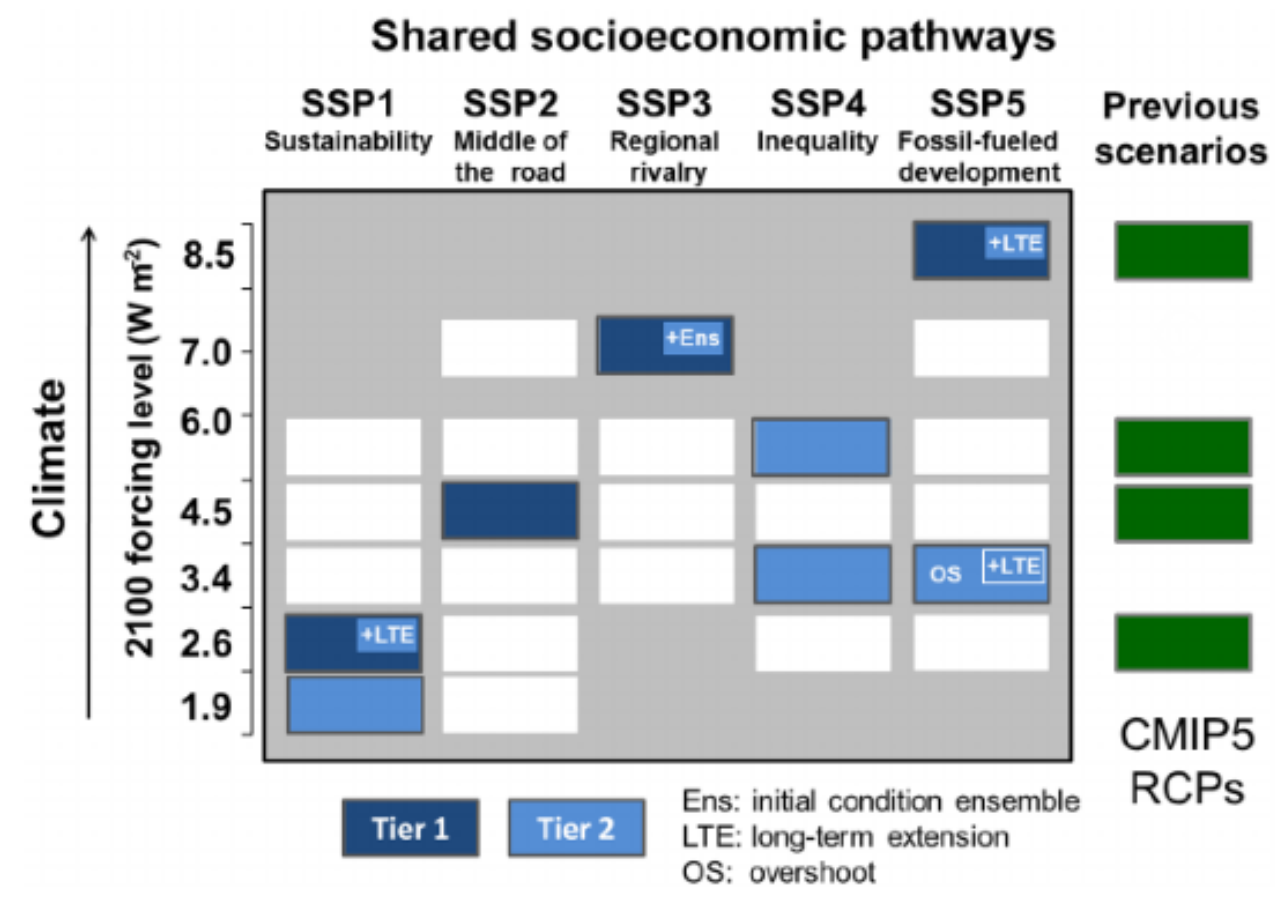

Figure 10 Matrix of shared socioeconomic pathways (SSPS) and representative concentration pathways (RCPs, forcing level). Taken from O'Neill et al. (2016).

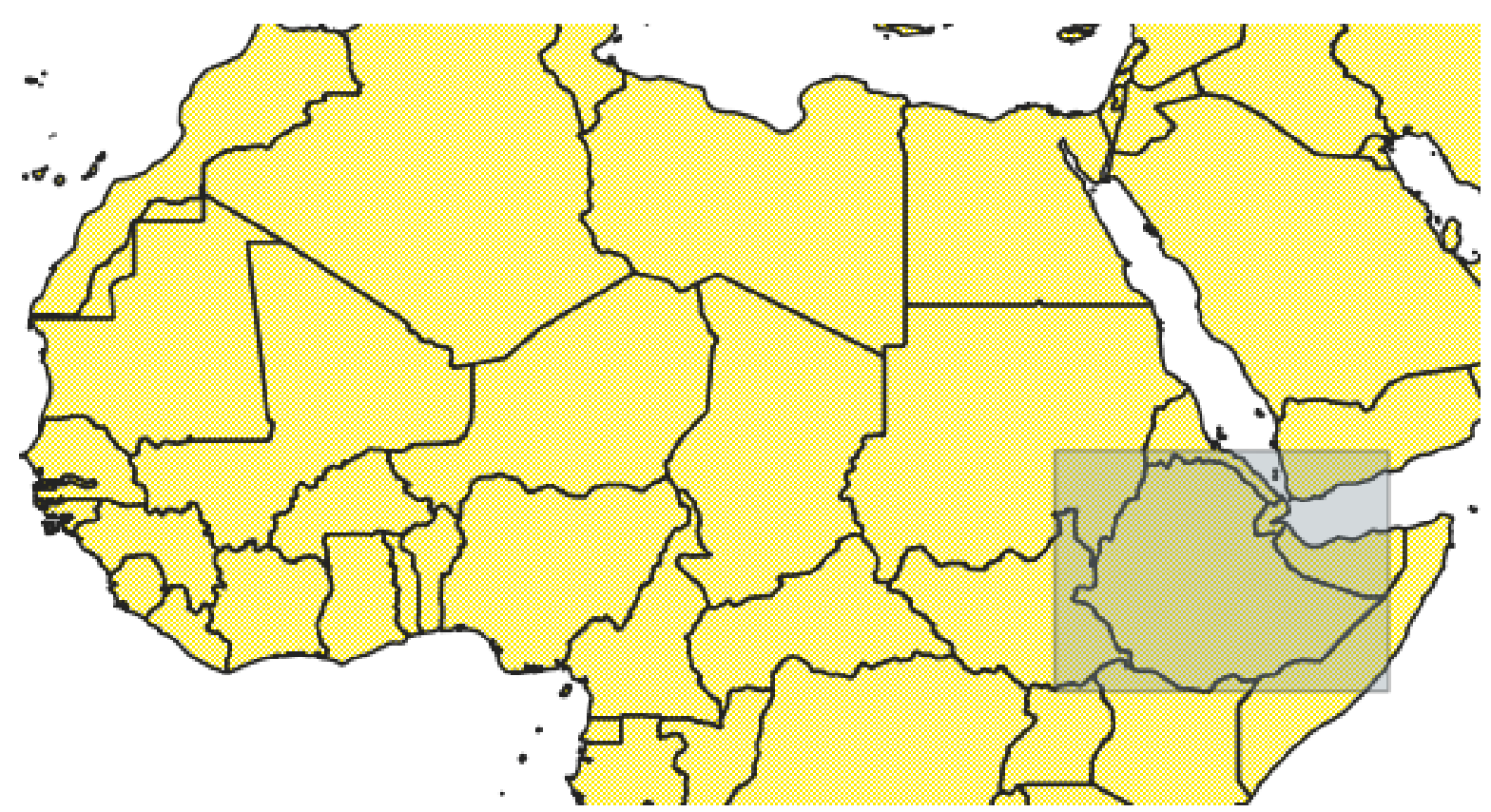

Figure 11 Area encompassed to calculate average yearly precipitation in climate scenarios (lat: $15^{\circ}$ to $3.5^{\circ}$, lon: $32^{\circ}$ to $\left.48^{\circ}\right)$. 


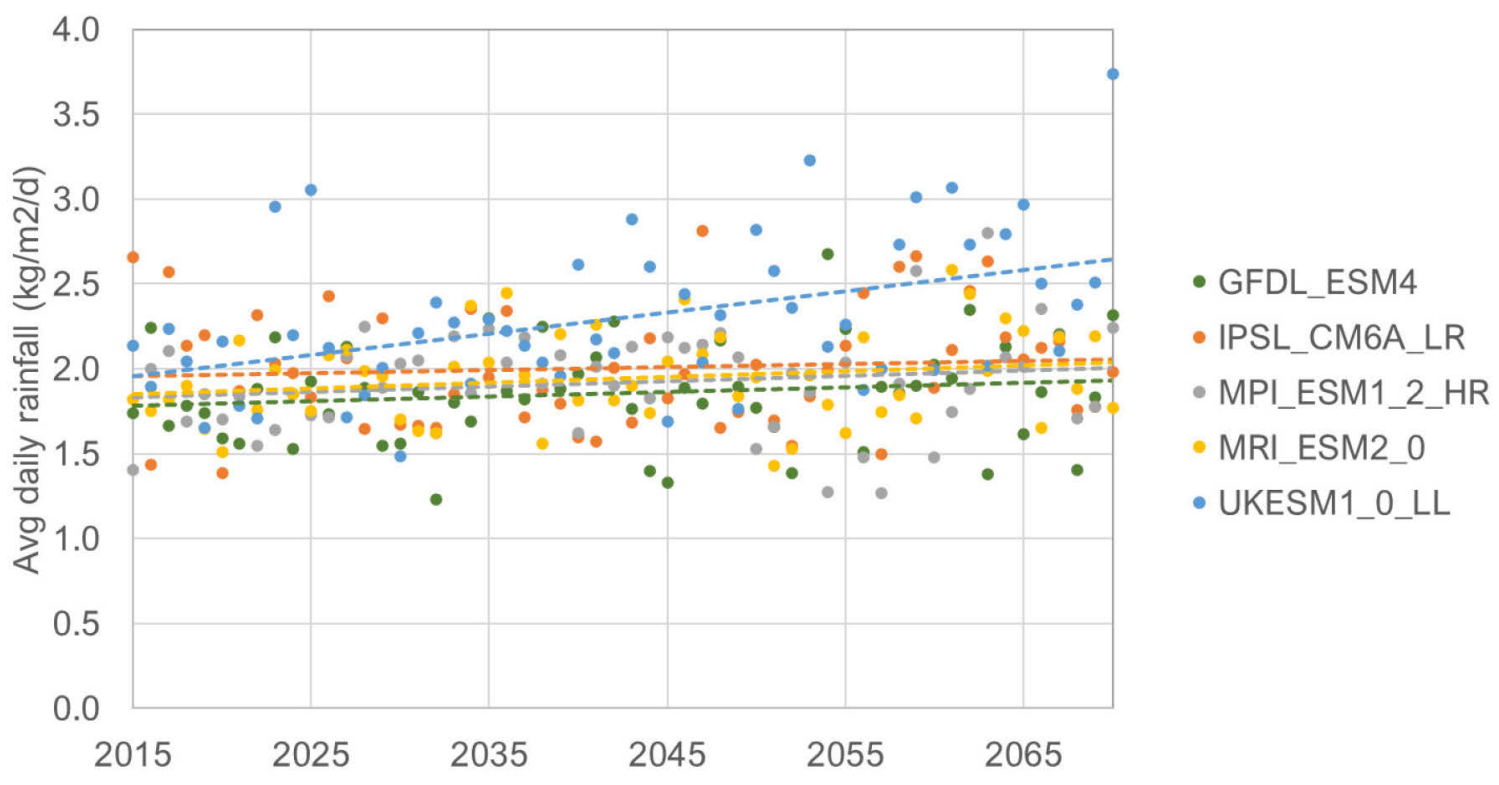

Figure 12 Predicted average daily precipitation in Ethiopia in the years 2015 to 2070 by five global circulation models (GCMS) in the scenario SSP3-RCP7.0. 
Table 11 Settings used for each simulation with LPJmL.

\begin{tabular}{|c|c|c|c|c|c|c|c|}
\hline Setting & Spin-up 1 & Spin-up 2 & Historic Run & Calibration $\times 7$ & Scenario A \& B & Scenario C & Scenario D \\
\hline Simulation type & Spinup & Spinup & Historic Run & Historic run & Historic run & Future run & Historic run \\
\hline Climate data & CRU & CRU & CRU & W5E5 & W5E5 & ISIMIP3b & W5E5 \\
\hline Purpose & $\begin{array}{l}\text { To "fill" water \& C } \\
\text { pools. }\end{array}$ & $\begin{array}{l}\text { To simulate agricultural } \\
\text { use of the soil. Reach } \\
\text { soil balance. }\end{array}$ & Simulate up to 1979. & $\begin{array}{l}\text { Calibrate LAImax with } \\
\text { historical yields }\end{array}$ & Simulate current agriculture. & $\begin{array}{l}\text { Simulate future } \\
\text { agriculture }\end{array}$ & $\begin{array}{l}\text { Simulate current } \\
\text { agriculture at potential } \\
\text { level. }\end{array}$ \\
\hline FROM_RESTART & Comment out & Define & Define & Define & Define & Define & Define \\
\hline ISRANDOM $^{1}$ & Define & Define & Define & Comment out & Comment out & Comment out & Comment out \\
\hline BENCHMARK_LAI & Comment out & Comment out & Comment out & Define. Set 1-7 & Comment out & Comment out & Define. Set to 7 \\
\hline WITH_LAIMAX_CFT & Define & Define & Define & Comment out & Define & Define & Define \\
\hline USE_RADIATION ${ }^{2}$ & Comment out & Comment out & Comment out & Define & Define & Define & Define \\
\hline WITH_LANDUSE & NO_LANDUSE & LANDUSE & LANDUSE & LANDUSE & LANDUSE & LANDUSE & LANDUSE \\
\hline IRRIGATION & NO_IRRIGATION & LIM_IRRIGATION & LIM_IRRIGATION & LIM_IRRIGATION & LIM_IRRIGATION & LIM_IRRIGATION & LIM_IRRIGATION \\
\hline Radiation setting: & RADIATION & RADIATION & RADIATION & RADIATION_LWDOWN & RADIATION_LWDOWN & RADIATION_LWDOWN & RADIATION_LWDOWN \\
\hline Spin-up years & 5000 & 390 & 0 & 0 & 0 & 0 & 0 \\
\hline First year of sim. & 1901 & 1901 & 1901 & 1979 & 1979 & 2016 & 1979 \\
\hline Last year of sim. & 1901 & 1906 & 2009 & 2016 & 2016 & 2050 & 2016 \\
\hline Input restart file & None & File A & File B & File C & File C & File E & File C \\
\hline Output restart file & File A & File B & File C & None & File $D \& E$ & None & None \\
\hline Write restart at yr: & 1840 & 1901 & 1979 & 2015 & 2015 & None & 2015 \\
\hline
\end{tabular}

Write restart at yr:

File B

2015

2015

2015 
Table 12 Dry matter content assumed for the crop functional types (CFTs). Values for the CFTs Temperate Roots, Tropical Roots, and Sunflower are not reported because the production area in Ethiopia was zero (in case of the roots due to misclassification of the crops, see Section 6.1.1).

\begin{tabular}{llll} 
CFT & Dry Matter Content $(\mathrm{gDM} / \mathrm{gFM})$ & Main Crop & Source \\
Temperate Cereals & 0.87 & Wheat & GYGA \\
\hline Rice & 0.86 & Rice & GYGA \\
\hline Maize & 0.85 & Maize & Feedipedia (2020) \\
\hline Tropical Cereals & 0.88 & Teff & Feedipedia (2020) \\
\hline Pulses & 0.89 & Chickpea & - \\
\hline Temperate Roots & - & - & - \\
\hline Tropical Roots & - & - & - \\
\hline Sunflower & - & - & GYGA \\
\hline Soybean & 0.89 & Soybean & Mrema et al. (2012) \\
\hline Groundnuts & 0.93 & Groundnut & Feedipedia (2020) \\
\hline Rapeseed & 0.92 & Rapeseed & GYGA
\end{tabular}

Table 13 Simulated average yield (ton/ha) for 13 crop functional types (CFT) with LPJmL at Maximum Leaf Area Index (LAImax) 1 to 7, and average yields according to FAOSTAT. Averages were computed over years 2000 to 2016. Simulated yields that are closest to the FAOSTAT yield are highlighted and their corresponding LAImax value was used for further simulations. Yields of the CFTs Temperate Roots, Tropical Roots, and Sunflower are not available (na) because the production area in Ethiopia was zero.

\begin{tabular}{|c|c|c|c|c|c|c|c|c|}
\hline \multirow[b]{2}{*}{ CFT } & \multicolumn{7}{|c|}{ LAImax } & \multirow[b]{2}{*}{ FAOSTAT Yield } \\
\hline & 1 & 2 & 3 & 4 & 5 & 6 & 7 & \\
\hline Temperate Cereals & 1.6 & 3.5 & 5.4 & 7.2 & 9.1 & 10.9 & 12.8 & 1.9 \\
\hline Maize & 0.7 & 2.6 & 4.7 & 7.4 & 9.7 & 10.7 & 11.5 & 2.5 \\
\hline Tropical Cereals & 0.6 & 1.2 & 1.8 & 2.5 & 3.1 & 3.7 & 4.4 & 1.6 \\
\hline Temperate Roots & na & na & na & na & na & na & na & 10.5 \\
\hline Tropical Roots & na & na & na & na & na & na & na & 16.3 \\
\hline Sunflower & na & na & na & na & na & na & na & 0.7 \\
\hline Soybean & 0.5 & 1.1 & 1.8 & 2.5 & 3.2 & 4.0 & 4.8 & 1.4 \\
\hline
\end{tabular}


Table 14 Average yields of Temperate cereals, Rice, Maize, and Tropical Cereals in each scenanario. Data from 1986-2016 and 2036-2065 was averaged for the future and current situation respectively.
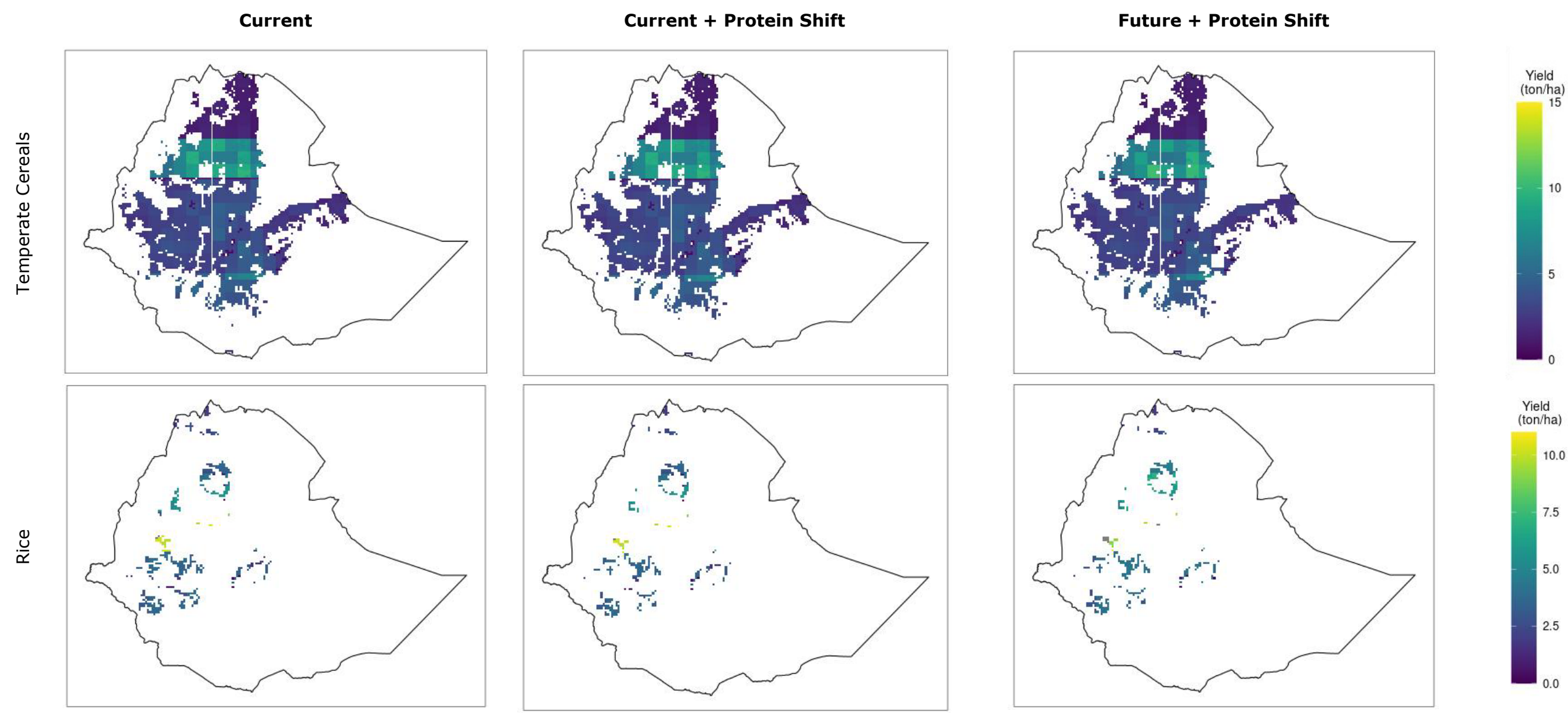

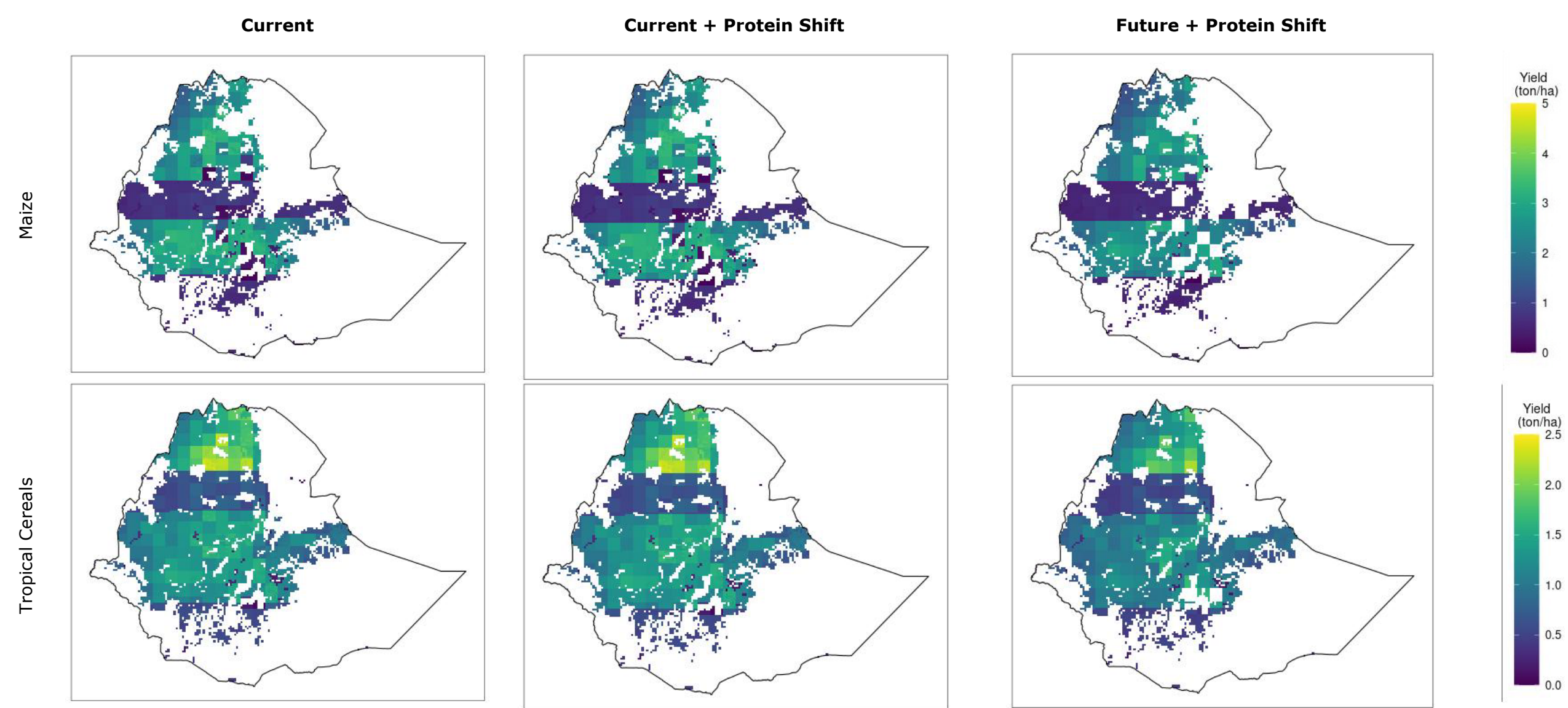

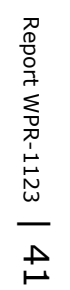

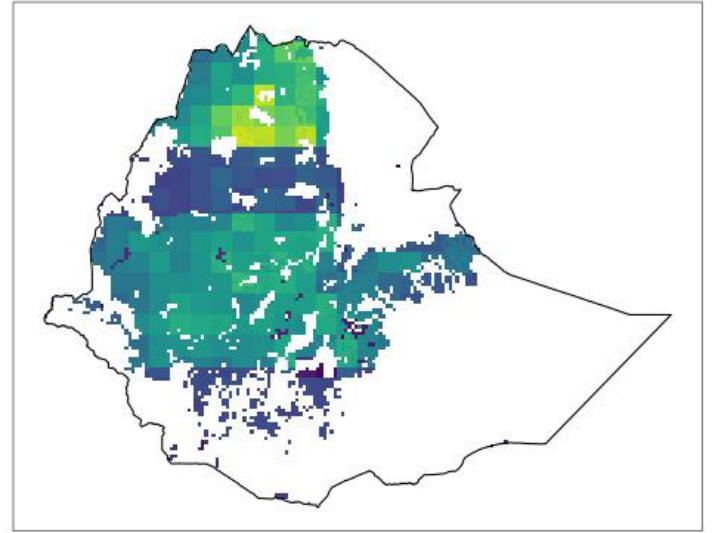




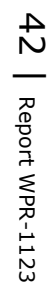
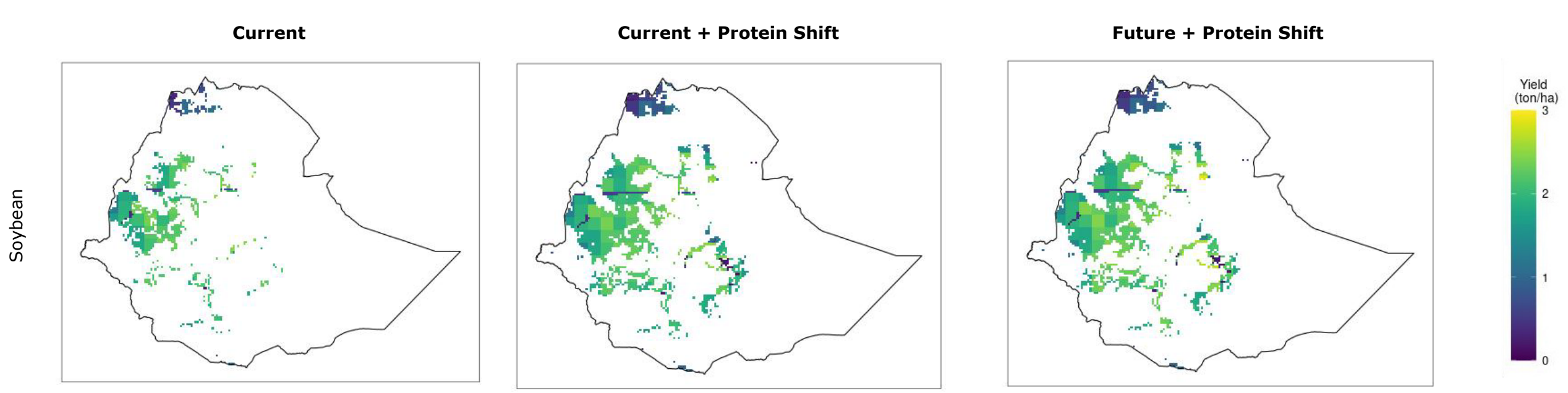
Corresponding address for this report:

P.O. Box 16

6700 AA Wageningen

The Netherlands

$\mathrm{T}+31(0) 317480700$

www.wur.eu/plant-research

Report WPR-1123
The mission of Wageningen University \& Research is "To explore the potential of nature to improve the quality of life". Under the banner Wageningen University \& Research, Wageningen University and the specialised research institutes of the Wageningen Research Foundation have joined forces in contributing to finding solutions to important questions in the domain of healthy food and living environment. With its roughly 30 branches, 6,800 employees $(6,000 \mathrm{fte})$ and 12,900 students, Wageningen University \& Research is one of the leading organisations in its domain. The unique Wageningen approach lies in its integrated approach to issues and the collaboration between different disciplines. 



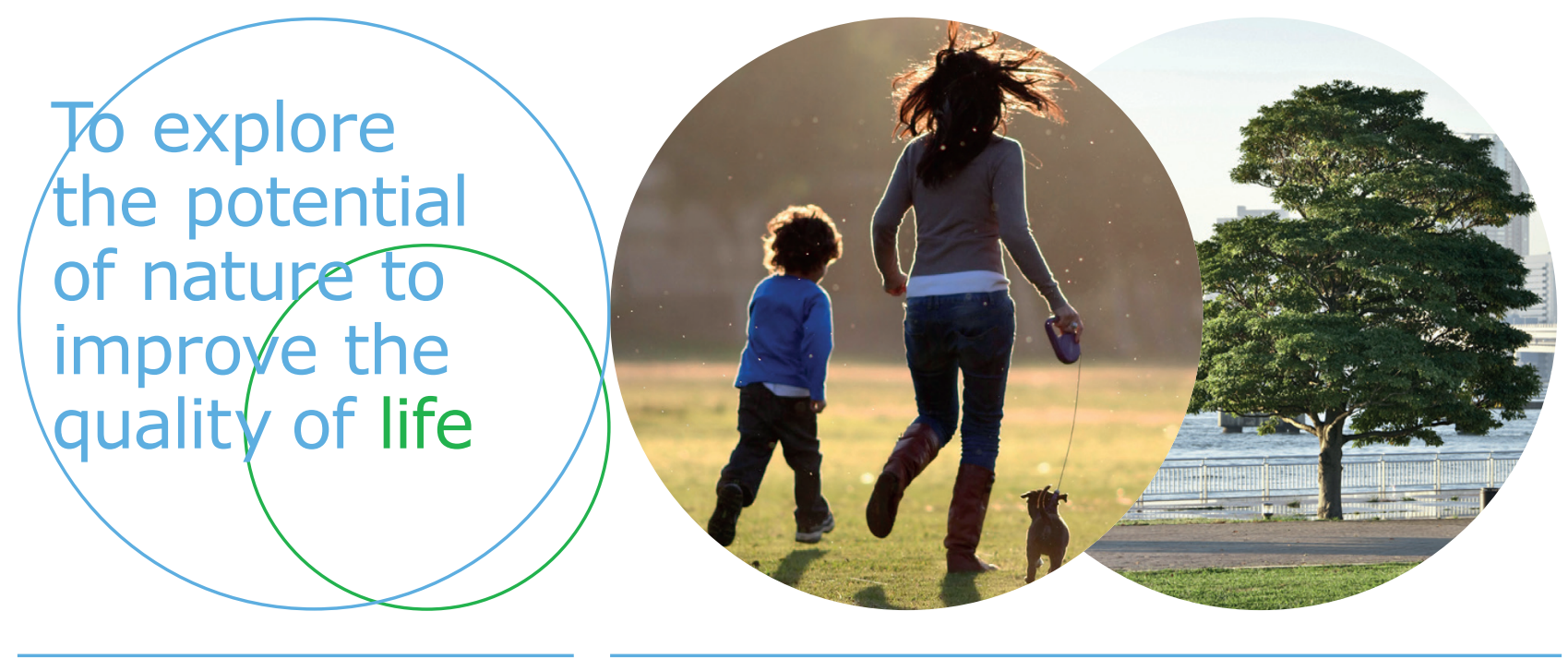

Corresponding address for this report:

P.O. Box 16

6700 AA Wageningen

The Netherlands

T +31 (0)317480700

www.wur.eu/plant-research

Report WPR-1123
The mission of Wageningen University \& Research is "To explore the potential of nature to improve the quality of life". Under the banner Wageningen University \& Research, Wageningen University and the specialised research institutes of the Wageningen Research Foundation have joined forces in contributing to finding solutions to important questions in the domain of healthy food and living environment. With its roughly 30 branches, 6,800 employees $(6,000 \mathrm{fte})$ and 12,900 students, Wageningen University \& Research is one of the leading organisations in its domain. The unique Wageningen approach lies in its integrated approach to issues and the collaboration between different disciplines. 